\title{
No labirinto das fontes do Hospício Nacional de Alienados
}

\author{
Inside the maze of sources on the \\ National Asylum for the Insane
}

\section{Cristiana Facchinetti}

Pesquisadora do Departamento de Pesquisa e professora do Programa de Pós-graduação em História das Ciências e da Saúde/Casa de Oswaldo Cruz (COC)/Fundação Oswaldo Cruz (Fiocruz) cfac@coc.fiocruz.br

\section{Andrea Ribeiro}

Bolsista Tec-tec Faperj/Fiocruz (2008-2009)

aoribeiro@gmail.com

\section{Daiana Crús Chagas}

Mestre em História das Ciências e da Saúde (COC/Fiocruz) daianacrus@gmail.com

\section{Cristiane Sá Reis}

Bolsista Pibic-CNPq/Fiocruz Cris.sa.reis@hotmail.com

Av. Brasil, 4036/400

21040-361 - Rio de Janeiro - RJ Brasil

cfac@fiocruz.br
FACCHINETTI, Cristiana et al. No labirinto das fontes do Hospício Nacional de Alienados. História, Ciências, Saúde - Manguinhos, Rio de Janeiro, v.17, supl.2, dez. 2010, p.733-768.

\section{Resumo}

Os documentos clínicos, periódicos, relatórios, leis, decretos e imagens ora apresentados referem-se ao Hospício Nacional de Alienados, durante o período em que Juliano Moreira foi seu diretor, além de diretor da Assistência a Alienados do Distrito Federal (1903-1930). O material será reunido na Biblioteca Virtual em Saúde para América Latina e Caribe - História e Patrimônio Cultural da Saúde (com informações sobre diagnósticos, pacientes, terapêuticas e funcionamento do Hospício Nacional) em 2011. O conjunto de fontes oferece elementos para a reflexão sobre a atuação de eminentes psiquiatras cariocas perante a alienação e a sociedade brasileira na Primeira República, quando a psiquiatria nacional se institucionalizava e ganhava apoio estatal.

Palavras-chave: história da psiquiatria; Hospício Nacional; fontes clínicas; fontes arquivísticas; Brasil.

\section{Abstract}

Thearticle presents a set of clinical documents, periodicals, reports, laws, decrees, and images about the National Asylum for the Insane dating from Juliano M oreira's tenureas its director and as director of Federal District Assistance for the Insane. In 2011, the material will be available at the site of the Virtual Library on Health in Latin America and the Caribbean: Health History and Cultural Heritage. This material, which includes information on diagnoses, patients, treatments, and the operation of the National Asylum, enhances our ability to investigate the activities of eminent psychiatrists in Rio deJaneiro and their attitudes towards "insanity" and Brazilian society under the First Republic, when Brazilian psychiatry was first gaining institutional form and winning government support.

Keywords: history of psychiatry; Hospício Nacional de Alienados; clinical sources; archival sources; Brazil. 


\section{A construção de um acervo de fontes para a história da psiquiatria no Rio de Janeiro}

Em 2003, em meio a uma pesquisa sobre a história da psiquiatria brasileira (Facchinetti, 2004) tivemos acesso a um grande acervo de documentos clínicos sob a guarda do Instituto Municipal Nise da Silveira, advindo da primeira instituição brasileira para tratamento dos alienados, inaugurada em 1852, o Hospício Nacional. ${ }^{1}$

Ao levantarmos a documentação lá depositada, buscávamos auxílio para discutir a passagem da hegemonia do alienismo francês para a psiquiatria alemã nas práticas asilares do Distrito Federal das primeiras três décadas do século XX. Até então havíamos trabal hado apenas com artigos científicos de alienistas publicados no periódico Arquivos Brasileiros de Psiquiatria, Neurologia e Ciências Afins. $\mathrm{O}$ acesso aos prontuários permitiria verificar a mudança proclamada pela revista, bem como vislumbrar suas consequências para os indivíduos tratados como alienados naquele período, uma vez que o periódico parecia ser uma espécie de divulgador dos novos modelos que a Sociedade Brasileira de Psiquiatria, Neurologia e Medicina Legal ${ }^{2}$ propunha. Questão correlata era compreender o que era a doença mental para os médicos brasileiros, no período em que a psiquiatria se institucionalizava e ganhava apoio público. Orientava, portanto, nossas leituras a ideia de que a loucura, como doença mental, deve ser tratada como objeto histórico à luz da sociedade e da ciência do período (Foucault, 1978, 2006; Rosenberg, Golden, 1992).

Para uma melhor compreensão do funcionamento do Hospício, iniciamos em 2004 uma pesquisa sobre a instituição, desde seus primórdios, em bibliografia secundária (Machado et al., 1978; Engel, 2001; Portocarrero, 2002; Jacó-Vilela, Espírito Santo, Pereira, 2005) e estabelecemos como marco os anos de 1900 a 1930, período crucial para a institucionalização e o reconhecimento da psiquiatria e da assistência no cenário científico local. ${ }^{3}$

Nesse empreendimento, dois objetivos se tornaram prioritários: de um lado, apreender o cotidiano do hospício, o percurso e o destino de seus moradores, bem como as mudanças ao longo do período investigado; de outro, reunir as fontes em um instrumento capaz de viabilizar novas pesquisas sobre o tema. Este último objetivo se explica ao considerarmos que o processo de criação e supressão contínuas de instituições exigia a relocação de uma grande massa de internos entre as diversas in stituições públicas sob a jurisdição da Assistência a Alienados, ocasionando dispersão das papeletas dos pacientes, o que dificulta a pesquisa com essas fontes. Vejamos como se deu a multiplicação de instituições pertencentes à Assistência.

O Hospício Nacional foi entregue à Assistência a Alienados no começo da República, em 1890, junto com as colônias da Il ha do Governador (São Bento e Conde de Mesquita), também inauguradas no mesmo ano (Amarante, 1982) no esforço de resolver os problemas da superlotação da Seção Pinel, ou Primeira Seção do Hospício Nacional.

Outras instituições subordinadas à Assistência foram paulatinamente criadas. Em 1893, por exemplo, o decreto de 1.559, de 7 deoutubro, criou o Pavil hão de Observação, instituição anexa ao Hospício e sua porta de entrada, que desde então foi dirigido pelo catedrático de clínica psiquiátrica e de moléstias nervosas da Faculdade de Medicina do Rio de Janeiro, e não pelo diretor do Hospício. ${ }^{5}$ 
Em 1905 três estabelecimentos particulares juntaram-se à Assistência: a Casa de Saúde Dr. Eiras, a Casa de Saúde Doutor Leal e a de S. Sebastião (Brasil, MJNI, 1905, Anexo D)6; e em 1921 foi a vez do Sanatório Botafogo e da Casa de Saúde Dr. Abilio.

Em 1911 inaugurou-se a Colônia de Alienadas de Engenho de Dentro, que recebeu da Seção Esquirol o excedente de mulheres 'indigentes' do Hospício Nacional (Brasil, MJNI, 1911, 1912). Em 1918, após Gustavo Riedel assumir a direção (1918-1932), passou a se chamar Colônia de Alienados de Engenho de Dentro e a abrigar também pacientes masculinos. Deixando de ser apenas um anexo para auxiliar no excesso de contingente do Hospício Nacional, a Colônia sofreu importantes modificações em sua estrutura. Abrigou um serviço heterofamiliar de assistência extra-hospitalar, bem como o primeiro órgão de divulgação da higiene mental, o Instituto de Profilaxia Mental (1921), que originou, em 1923, a Liga Brasileira de Higiene Mental. A ênfase na profilaxia das doenças mentais, por sua vez, fez com que a colônia instaurasse o primeiro ambulatório psiquiátrico do Brasil (Ambulatório Rivadávia Correia). O interesse de Gustavo Riedel pela renovação do projeto psiquiátrico brasileiro redundou ainda na criação do Laboratório Experimental da Colônia de Psicopatas do Engenho de Dentro (1923) e da Escola de Enfermeiros Alfredo Pinto (Oliveira, 2004).

As modificações de seu projeto acabam por se firmar como proposta hegemônica em relação ao Hospício Nacional. Assim é que, na direção de Ernani Lopes, que substituiu Riedel quando este adoeceu e em meio à reestruturação do Ministério da Educação e Saúde Pública (Mesp) ocorrida em 1937, a Colônia foi ampliada e transformada em Colônia Gustavo Riedel para homens e mulheres. Em 1938, logo após Adauto Botelho ter assumido a direção da Assistência de Psicopatas e criar o Serviço Nacional de Doenças Mentais (SNDM) ${ }^{8}$, a colônia foi remodelada, passando a ser chamada de Centro Psiquiátrico Nacional, quando foi anunciada como substituta do Hospício Nacional. ${ }^{9}$ A transferência final do Hospício ocorreu em 1943. ${ }^{10} \mathrm{Na}$ Praia Vermelha restou o Pavilhão de Observação - que passou a se chamar Instituto de Psicopatologia - e o Instituto de Neurossífilis, hoje Instituto Philippe Pinel. ${ }^{11}$

Em 1921 foi inaugurado o Manicômio Judiciário (Brasil, 25 maio 1921), com o objetivo de retirar da Seção Lombroso, no interior da Seção Pinel do Hospício Nacional, os pacientes considerados perigosos. ${ }^{12} \mathrm{~A}$ partir de então, o Manicômio passou a receber os 'loucoscriminosos' encaminhados pela Justiça do Distrito Federal..$^{13}$

Em 1923 as colônias de alienados da Il ha do Governador foram fechadas e seus pacientes, transferidos para Jacarepaguá, nascendo assim a Colônia de Psicopatas Homens de Jacarepaguá, nos terrenos de um dos mais antigos engenhos de cana-de-açúcar da região (Venancio, 2008, p.6). ${ }^{14}$ A colônia recebeu diversos internos 'indigentes' da Seção Pinel do Hospício Nacional, assim como pacientes das antigas colônias da Ilha do Governador (Brasil, MJNI, 1922-1923, 1923). Foi renomeada Colônia Juliano Moreira em 1935 e passou a abrigar, a partir de 1938, parte dos homens e das mulheres transferidos do Hospício Nacional, que em 1943 terminava por fechar suas portas (Cassília, Venancio, 2007).

Quanto à Assistência a Alienados propriamente dita, em 1927 passou a se chamar Serviço de Assistência a Psicopatas, abrangendo não só o Distrito Federal mas todo o território nacional (Brasil, 10 jan. 1927, 23 maio 1927). Mesmo apósa mudança, os relatórios 
da Assistência continuaram a ser publicados até 1931 na pasta do Ministério da Justiça e Negócios Interiores (MJNI). ${ }^{15} \mathrm{~A}$ partir de então, a Assistência saiu do Departamento Nacional de Saúde Pública, ligado ao MJNI, e passou a integrar o Mesp (Brasil, 30 dez. 1931). Compunham-na o Serviço de Assistência a Psicopatas (de âmbito nacional) e a Divisão de Assistência a Psicopatas do Distrito Federal, que compreendia "o Hospital Nacional, o Manicômio Judiciário, as colônias especiais para homens e para mulheres, assim como os asilos-colônias para ébrios, epilépticos e atrasados mentais, que forem criados" (Brasil, 23 maio 1927). Em 1937, o ministério a qual estava subordinada passou a chamar-se M inistério da Educação e Saúde (MES), com a reestruturação administrativa promovida pelo titular da pasta, Gustavo Capanema (Melloni, 2009, p.26).16

Os efeitos dessas alterações institucionais e mudanças no organograma do governo se fizeram sentir na documentação, provocando a dispersão de fontes históricas relativas ao Hospício Nacional. Hoje, encontramos no Instituto Municipal Nise da Silveira (herdeiro do Centro Psiquiátrico Nacional) prontuários de internos daquele hospício desde meados do século XIX ao século XX, além de documentos clínicos dos pacientes que foram internos da Colônia do Engenho de Dentro e do próprio Centro Psiquiátrico (na mesma instituição estão os documentos administrativos do antigo Hospício). Já a documentação referente aos internados na Colônia da Ilha do Governador, aos transferidos do velho hospício e aos da Colônia de Jacarepaguá acham-se no Instituto M unicipal Juliano M oreira (onde também se encontra a documentação administrativa do Serviço Nacional de Doenças Mentais). Os papéis concernentes aos antigos pacientes do Pavilhão de Observação e do Instituto de Neuro-sífilis estão no Instituto de Psquiatria da Universidade Federal do Rio de Janeiro (Ipub) e no Instituto Philippe Pinel, respectivamente. Enfim, os documentos clínicos e laudos psiquiátricos dos internos da Seção Lombroso e do Manicômio Judiciário encontramse no Hospital de Custódia e Tratamento Psiquiátrico Heitor Carrilho. Tais instituições situam-se em diferentes esferas administrativas dos governos federal, estadual e municipal.

Quanto aos relatórios anuais do Hospício Nacional e da Assistência, parte deles se encontra no acervo do Instituto Municipal Nise da Silveira, mas fomos impedidos de trabal har com eles porque o acervo esteve fechado ao público, para recodificação de seus documentos, durante o ano de nossas pesquisas. Buscamos os relatórios da Assistência em outras instituições, mas, sem sucesso, tivemos de nos contentar com os relatórios do MJNI ao presidente da República. Esse documentos oficiais trazem ora a súmula, ora a reprodução de relatórios anuais de diversas instituições subordinadas ao Ministério, como o Museu Histórico Nacional, a Biblioteca Nacional, o Arquivo Nacional, e também a Assistência aos Alienados.

Formou-se, assim, um labirinto, que nossa equipe de pesquisa arriscou-se a desafiar.

\section{Banco de dados para a história da psiquiatria no Rio de Janeiro}

Apesar da abundância de fontes, as dificuldades de acesso, o estado em que elas se encontram, o risco de manuseá-las (para a integridade dos documentos e a saúde dos pesquisadores), a dispersão dos acervos e a carência de inventários são grandes obstáculos 
a sua utilização e publicação. Tendo isso em vista, tivemos a ideia de reuni-las, ao menos parcialmente, numa base de documentos, que acabou por se constituir não apenas de informações contidas em documentos clínicos produzidos no Hospício Nacional e no Pavilhão de Observação, entre 1900 e 1930. Com a adesão de outros pesquisadores ao método de armazenamento de informações de pesquisa, a base passou a contar também com documentos clínicos da Colônia Juliano Moreira, do final da década de 1930 e 1940, advindos da pesquisa de Ana Teresa A. Venancio, e do Manicômio Judiciário, da década de 1920 e 1930, material este proveniente da pesquisa de Flávio Edler (Facchinetti, Edler, Venancio, 2007). ${ }^{17}$

A princípio, a transposição desses prontuários para planilhas em Access foi feita de acordo com a estrutura da fonte de origem, de forma que os campos existentes nos prontuários eram transportados para as colunas, inserindo-se então as informações nas planilhas. Com o desdobramento do projeto, em 2006, houve a necessidade de se repensar a forma e a estrutura das planilhas, agora em Excel. Chegamos a um modelo de preenchimento dos campos que atendia à variedade de tipos de documentos - prontuários encontrados no Instituto Municipal Nise da Silveira, fichas do Instituto Municipal Juliano Moreira, livros de observação, pareceres e laudos periciais do Heitor Carrilho, e ainda livros de observação do Ipub. ${ }^{18}$ Elaboramos um manual de preenchimento, para padronizar a entrada dos dados no banco e uniformizar nomenclaturas; instrumento valioso para nos guiar por entre as fontes, serviu-nos igualmente para a discussão dos critérios de classificação e nomenclatura adotados.

Os documentos contêm informações de detal hamento variável: nomes, nacionalidade, endereço, ocupação, características físicas e mentais, diagnóstico, comportamentos etc. A Base de Dados de Documentos Clínicos se propôs a referenciar tudo isso tal como aparece na documentação, assim como as anotações feitas por cada médico. O objetivo foi construir uma base passível tanto de tratamento quantitativo e serial, quanto de uma análise qual itativa capaz de permitir a recuperação de traj etórias individuais e de grupo no ambiente asilar. ${ }^{19}$

A estruturação dessa base gerou rico material secundário, como o Glossário de Termos M édicos, a Lista de Médicos e de Diretores do Hospital Nacional ${ }^{20}$, além de amplo material informativo (textual e visual) sobre as seções e pavilhões do Hospício Nacional, sobre as instituições mantenedoras de acervo e sobre os diagnósticos da época.

O desdobramento das pesquisas, com a incorporação de novas fontes, permitiu a criação de outras bases de dados, como a de Relatórios Ministeriais, a Base de Imagens e a Base de Periódicos do Hospício Nacional (Facchinetti, Ribeiro, 2008). O material será reunido por meio da Biblioteca Virtual em Saúde para América Latina e Caribe - História e Patrimônio Cultural da Saúde.

\section{Documentos clínicos como fonte histórica}

Alguns autores vêm questionando a utilização de documentos clínicos em pesquisas sobre a história da psiquiatria no Brasil (Cunha, 1986; Engel, 2001; Facchinetti, Ribeiro, M uñoz, 2008; Jabert, 2008; M uñoz, 2010; Santos, 2008; Wadi, 2002). Apesar de sua relevância, é ainda insuficiente a sistematização das informações contidas nas fontes clínicas, de 
modo que não se pode considerar esgotada a questão das práticas psiquiátricas brasileiras e de seus condicionantes e referenciais.

Nesses documentos - sejam eles prontuários, fichas, livros de observação ou mesmo laudos periciais -, o discurso sobre a loucura distingue-se daquele encontrado em textos que tratam do tema sob o ponto de vista teórico e que pretendem apresentar um sistema interpretativo e científico para o fenômeno da loucura. Tampouco é possível equipará-los a textos de divulgação científica, com retórica própria para atingir o leitor leigo. Afinal, lidamos com os procedimentos levados a efeito pelo corpo médico-administrativo da instituição, no curso das práticas de observação, interpretação e interven ção, não na doença, mas em indivíduos considerados doentes, com vistas a sua cura (Jabert, 2008).

Assim, o trabal ho com esse tipo de fonte permite ver o perfil e o cotidiano da instituição, com seus médicos, seções e pacientes, assim como as práticas diagnósticas, terapêuticas e de controle a eles relacionados. As informações gerais e de cunho quantitativo nos levam a perfis de doentes de determinado período, hipóteses causais de doenças, relação entre sintomas e normas sociais, lutas internas entre diferentes grupos médicos por referenciais teóricos e classificações, e a mudanças paulatinas nos planos da conduta e tratamento.

Trata-se, além disso, de uma oportunidade para perceber como a sociedade carioca identificava e interpretava os loucos, esse 'outro' situado à margem da formação de novos cidadãos da República. Afinal, reunida e organizada no hospício, a loucura "configura formas de relação com o ambiente deste mundo que os condenou" (Cunha, 1986, p.115). Desse modo, a documentação clínica permite também o acesso a casos individuais que ilustram a experiência cotidiana da loucura através da aplicação de discursos a situações específicas, singulares (Muñoz, 2010; Wadi, 2002).

Transparece, assim, o que era loucura para o grupo social no qual estava inserido o indivíduo considerado doente. Podemos detectar os tipos de comportamentos identificados como sinais de sua insânia, que procedimento era adotado quando ela se manifestava e os fatores considerados causais.

Patenteia-se, em suma, como esse acontecimento era interpretado pelos diferentes atores que configuravam a loucura do período. Assim, por exemplo, os policiais que recolhem um homem por vadiagem, consideram-no suspeito de alienação mental e o enviam, ao Hospício Nacional, quando "afirmam que o acusado não tem meios de subsistência nem ocupação honesta, e que vive de meios ilícitos, ... como gatuno que é" (Livro de Observação, 1922).

Do mesmo modo, a opinião pública pode ser vislumbrada nas frequentes notas de jornal anexadas aos documentos clínicos, como esta, cuja manchete anunciava a tentativa de homicídio praticada por um indivíduo posteriormente internado: “Delirando? História misteriosa de 'moambas' e 'despachos', quis matar uma mulher e um homem e também está ferido". Ainda segundo o jornal, o homem apresentava aspecto "doente", sendo "evidente o seu mau estado psíquico e mental" (A Noite, s.d., citado em Muñoz, 2010, p.149).

A família e os vizinhos comparecem, igualmente, como atores nesses documentos, seja nas informações constantes nas fichas de observação, ou como testemunhas nos laudos de exame, como a seguir: 
Uma delas (fls. 38v.) disse que "não Ihe parece que uma pessoa normal, na idade e erudições [pal avra ilegível] da acusada, possa praticar os atos que ela praticou"; outra declarou (fls. 39) "que a primeira vez que a depoente viu a acusada não teve a impressão desetratar de uma pessoa anormal, poisconversara lucidamente; que, entretanto, quando a viu na del egacia notou nela muita nervosidade"; outra mais disse (fls. 39v.) "que desde a primeira vez quea acusada apareceu em casa da depoente que se Ihe afigurou não ser pessoa normal". Final mente, outra testemunha (fls. 42v.) declarou "quea acusada, pela maneira por que se apresentara na Polícia, pareceu ao depoente ser um pouco desequilibrada" (Laudo deexame..., 1932a).

Em consonância com os vizinhos, o médico que assina o laudo reiterou que a paciente não tinha "capacidade de imputação pelos atos delituosos que praticou", porque sendo "senhora de condição e nível sociais lisonjeiros, vem apresentando, na fase de climatérios em que se encontra, e em contradição com os seus hábitos anteriores, desordens do caráter e dos atos, vivendo em constantes conflitos domésticos, instável no modo de se conduzir, sem residência fixa, com desvios éticos evidentes, que culminaram no delito" (Laudo de exame..., 1932a).

Os documentos clínicos oferecem também uma visão privilegiada dos pacientes e de sua fala. Se para entender a loucura é necessário conhecer como experiências, discursos e acontecimentos transformaram o hospício como destino para alguns (Wadi, 2006, p.303307), os registros asilares "evidenciam sua resistência surda e constante, permitindo o estabelecimento de relações para as quais os historiadores estiveram muito desatentos" (Cunha, 1986, p.16). Assim, além de nos oferecer oportunidade de analisar a instituição, tais documentos nos dão acesso à experiência singular de sujeitos internados. Eles falam sobre sua condição através de laudos, jornais e fichas de observação. Podem fazêlo, por exemplo, afirmando e interpretando sua alienação: "Com relação a sua internação diznos que ela 'a deve ao seu próprio gênio' que é, assegura, a 'desgraça de sua vida'. Se não fora o mesmo, diz-nos a observada, 'não teria esbofeteado a minha patroa por me não querer pagar a mensalidade, bem como uma mulher e alguns guardas, na Casa de Detenção por motivos insignificantes'" (Laudo de exame..., 1932b). Sua voz nos nos chega também sob a forma de história de vida:

era obediente, ... brincava naturalmente com os irmãos e as meninas da vizinhança. Indagando nós por que nos dizia que brincava com as meninas enão com os meninos, retorquiu-nos que não brincava com meninos porque sua mãe formal mentel he proibia. Falecen do o pai, quando A. tinha a idade indicada acima, foi colocada em casa de uma de suas irmãs pela genitora. Esta irmã, porém, maltratava-a porque não sabia fazer os serviços, não obstante ser obediente e procurar tomar conta dos sobrinhos, que eram pequenos. Por causa dos maus tratos, fugiu A. para casa de outra irmã, a qual, contudo, não a pôde guardar porque não dispunha de recursos que permitissem manter outra pessoa em casa. A mãe da observada colocou-a então, em casa de família do Coronel E. C., onde permaneceu A. dos 7 até os 14 anos. Diz que nesta casa era dócil, que gostava e gosta dos patrões, que sempre foram bondosos para ela. Nunca frequentou escola (Laudo deexame..., 1928).

O sujeito internado fala ainda em sua própria defesa, contra aqueles que o puseram na condição de alienado: 


\begin{abstract}
Arrancar uma in defesa mulher de sua casa on de pediu agasal ho e proteção, sob falsas al egações, auxiliado pela polícia e levá-la à força e arbitrariamente ao hospício, onde esse velhaco [o marido] inventou as maisinfames mentiras para conseguir a minha internação! ... No hospício eu fui tratada como uma criminosa. Não tiveram a mínima deferência comigo, quanto ao meu estado de saúde e meus hábitos ou costumes como estrangei ra, embora eu chamasse por isso no dia imediato ao da internação ao Dr. Henrique Roxo. ... Desgraçada a sorte dos pobres lá dentro, sem proteção de fora! (O IX M andamento..., 14 jul. 1925, p.6, citado em Muñoz, 2010, p.206).
\end{abstract}

A forma também é importante perspectiva de análise desses documentos. Entre 1900 e 1930, o Hospício Nacional utilizou três modelos de prontuários ${ }^{21}$ para o registro de informações sobre os pacientes lá internados, traduzindo as mudanças teóricas, políticas e administrativas em curso no asilo. Tais mudanças foram difundidas extramuros através de periódicos, congressos e artigos. Na gestão de Juliano Moreira ${ }^{22}$ como diretor da Assistência a Alienados, observa-se claramente o esforço de implantar um modelo teórico, político, administrativo e clínico capaz de introduzir a psiquiatria kraepelinianas, considerada a mais científica, moderna e eficaz para o tratamento de alienados.

Apesar das diferenças entre modelos de prontuários, fichas e livros de observação no período pesquisado, foi possível identificar neles uma mesma rotina metodológica no que diz respeito ao preenchimento das informações dos pacientes. Assim, na seção inicial de todos os modelos figuram os dados pessoais: nome, endereço/procedência, o requerente (da internação), profissão, nação, cor, sexo, idade, naturalidade, constituição, temperamento, estatura, estado civil e profissão. Logo após, seção (onde foi internado), classe (se é ou não pensionista, isto é, pagante), diagnósticos, médicos e diretor (do período), tempo de internação (através das datas de entrada, alta, transferência e de falecimento), causa mortis. Há ainda os campos transferência (para onde foi e/ou de onde veio o paciente), terapêutica (muitas vezes indicam-se apenas as cirurgias e os exames feitos), correspondência (com observações acerca de quem se comunicou por escrito com o diretor do hospício sobre o caso, ou a quem se deveria comunicar alta, transferência ou falecimento do paciente) e haveres (bens que o paciente possuía ao dar entrada no hospício). Nas fichas gerais de observação (dos acervos do Instituto Juliano Moreira e do Hospital Heitor Carrilho), consta também a história do crime, caso o paciente tenha cometido algum.

Tais informações permitiam à Assistência fazer as estatísticas necessárias à construção de dados quantitativos e comparativos ao modo de Kraepelin. Tais estatísticas, que aparecem nos relatórios dirigidos ao MJNI, demonstram a preocupação dos gestores da Assistência em articular, também com apoio em Kraepelin, classe social, gênero, estado civil, raça, nacionalidade e profissão, na busca de substratos objetivos e científicos para fundamentar os diagnósticos, como bem analisa Engstrom (2007, p.392).

A seção seguinte dos documentos é constituída por observações, mais ou menos detal hadas, sobre a história de vida do paciente e suas heranças familiares. Sabemos, assim, se os ascendentes maternos e paternos estavam vivos, se haviam sofrido de alienação, se tiveram sífilis, tuberculose ou eram al coólicos. Outros parentes são mencionados, em especial irmãos, com doença mental ou moléstia nervosa, histeria, epilepsia ou paralisia. As observações costumam referir-se ao nascimento, infância e adolescência do observado - 
doenças infantis ou nervosas, convulsões, febres, ataques - e, na fase adulta, hábitos e doenças sexuais, filhos e abortos, hábitos alcoólicos, presença ou não de infecção sifilítica, histórico de histeria, epilepsia ou loucura.

A despeito da proposta teórica, nem sempre a anamnese era tão detalhadamente reproduzida nas fontes. Ao contrário do que ocorre nas fichas e livros de observação, por exemplo, na maioria dos prontuários esses quesitos são respondidos de forma bastante reduzida. Muitos são parcamente preenchidos. Isso não chega a causar surpresa, visto que o Hospício Nacional atendia principalmente à população carente do Distrito Federal e suas cercanias.

Segundo verificamos (Facchinetti,2006), o número de pagantes girava em torno de 1\% da população do Hospício Nacional. Os internos eram uma mescla de indivíduos com pouco ou nenhum vínculo com o mercado formal de trabalho, a exemplo de E.M, que, envolvido em "frequentes arruaças, era violento, bebia e não tinha profissão definida" (Prontuário, 1919). Predominavam os semianalfabetos e analfabetos, considerados de "nível intelectual apoucado" (Prontuário, 1902), como é o caso da paciente que "lê correntemente; negou-se porém a escrever, ficando muito emocionada e trêmula nesta ocasião" (Prontuário, 1909).

A al ta taxa de mortal idade e baixa expectativa de vida eram características da população de internos. Sobre muitos deles era impossível realizar uma anamnese completa, por falta de informações e lembranças, como o paciente que "pouco pode informar acerca de sua família, porque com sete anos foi colocada por sua mãe, em casa de família estranha, onde esteve até os quatorze anos, nunca mais tendo convivido com seus parentes" (Laudo de exame..., 1928). Mas, ainda que nem sempre completamente preenchidos, os documentos clínicos chamam a atenção por denotar a insistência com que se buscavam informações sobre a história familiar do paciente, evidenciando as teorias psiquiátricas que norteavam os profissionais durante o processo diagnóstico, pois o registro de ocorrências na história de vida do paciente traz implícitas as indicações de Kraepelin de que se estude longitudinalmente a marcha da moléstia mental (Jablensky, 2007). Assim é que as fichas de observação e os laudos são repletos de informações como estas:

Do ponto de vista pessoal, F. refere-se a uma infância um tanto doentia, era, segundo diz, muito "fraca e anêmica". O uviu certa vez sua mãe dizer que, em criança, tinha tido convulsões, masnada se sabe de mais positivo neste particular, além desta vaga referência. Aos sete anos teve varíola. Em 1918, foi acometida gravemente de gripe. Até pouco tempo, segundo diz, não fazia uso do álcool. No Hospital São Francisco, certa vez, teve necessidade de ser submetida a uma operação cesariana. De doen ças venéreas men ciona apenas leve infecção gonocócica. Nos antecedentes sociais, pouco há que referir: a vida escolar fez-se normal mente, casou-se aos quinze anos de idade, mas, um pouco depois, viu-se obrigada a deixar a companhia do marido que a mal tratava e, segundo informa, não tinha bom caráter nem profissão definitiva. Teve dois filhos eal guns abortos (Laudo deexame..., 1929).

O detal hamento das perguntas sobre antecedentes familiares, progressão de síndromes nas famílias e nos próprios indivíduos segue o curso de investigações que constituiu a psiquiatria deKraepelin, tal como elea prescreveem seu manual (Weber, Burgmair, Engstrom, 2006), mas mantém, ao mesmo tempo, as interpretações de Morel e Magnan sobre a 
Cristiana Facchinetti et al.

degeneração (Coffin, 2003; Engstrom, 2007). O subtítulo "antecedentes mórbidos hereditários" já denuncia a perspectiva de interpretação da história familiar dos internos, como a que segue, a informar sobre tuberculose, alcoolismo, sífilis e perturbações mentais na família da observada, marcando-a com a pecha da degeneração:

Seu pai, que fal eceu na Bahia, em consequência detuberculose pulmonar, era al coolista inveterado. Um dos seustios, irmão do seu pai, faleceu igualmentede tuberculose e com perturbações mentais ligadas também ao álcool. Sua mãe morreu atropelada por um auto caminhão, no dia 23 de março desteano, quando procurava tomar um bondena Rua 24 de Maio. Dos seus oito irmãos, um é genioso, impulsivo, rixento edado ao uso do álcool; outro teria morrido, ao que se apura das informações colhidas, aos 33 anos de idade, em consequên cia desífilis; outra, do sexo feminino, fal eceu com perturbações mentais, após um parto laborioso (Laudo de exame..., 1927).

Não é, pois, inesperada a conclusão dos psiquiatras, plenamente embasados em Morel e Magnan:

A examinada, gravada por taras psicopáticas hereditárias man ifestas, tem a definir a sua personalidade os requisitos da constituição hiperemotiva de Leupré, com traços histéricos evidentes. Haven do procriado prole excepcional mente numerosa - 23 gestações-, com muitos abortos evários filhos falecidos em ten ra idade, exemplifican do assim a fórmula "multinatal idadee poliletal idade", que definea descen dência dosheredoal coolistas ou das pessoas de frágeis e anormais con dições biológicas, real izou aos quarenta e cinco anos, quando já semostraram os sinais de um climatério precoce, um delito de morte, discordantedosseus princípios religiosos e desua formação moral (Laudo de exame..., 1927).

Como se pode observar, um dos aspectos fundamentais do diagnóstico era o uso ou abuso de bebidas alcoólicas - seja pelo observado ou por algum familiar. As drogas seriam capazes de afetar o cérebro e provocar mudanças patológicas de humor, agressividade e ciúme, acelerando a degeneração do indivíduo, o que é consonante com a preocupação da psiquiatria organicista al emã e dos teóricos franceses da degeneração (Coffin, 2003; Engstrom, 2007). Algumas vezes, utilizava-se a Prova de Gudden para uma avaliação 'objetiva' de tolerância ou tendência à embriaguez patológica. Nesse caso, o alienista administrava cerca de $20 \mathrm{~cm}^{3}$ de álcool e observava o examinado por uma hora (Facchinetti, 2005). O discurso psiquiátrico do período ligava fortemente à degeneração e à loucura os efeitos do álcool no indivíduo e em seus descendentes.

O campo Observação do prontuário traz também questões relativas à moléstia mental que levara o paciente a ser internado na instituição. Buscavam-se identificar transformações de comportamento do pacientee se al gum acontecimento mais recentepoderia ter deflagrado a enfermidade. Nessa parte, encontram-se informações sobre quando e como começou a moléstia em curso, e como foi caracterizada pelos familiares, pela polícia ou pelo próprio indivíduo. São descritas ainda manifestações da doença, atos agressivos, perda de afeto pelos membros familiares, maus costumes, mudanças de hábito etc., mantendo-se uma preocupação com as causas precipitantes da doença, que percorream a medicina mental desde o alienismo de Pinel. Leiamos o relato abaixo:

Confessa que no dia em que se verificou o crime, às dez horas da manhã, seu esposo, ao chegar do trabalho, comunicou que tinha arranjado outra mulher para viver consigo e 
que ela tratasse de deixar sua casa. A paciente não se conformou com esta afirmativa, dizendo quenão se opunha à união dele com outra mulher, entretanto, que ele fosse à Glória, on de era funcionário, e fizesse uma declaração de que deixava uma mensal idade para a mesma, consignada na fol ha de pagamento. Com esta declaração exasperou-seo marido, indo em seguida dormir, admoestando-a, porém, de que não desejava tornar a vêla naquela casa, quando acordasse. Do quese passou daí por diante, atéo dia seguinte, denada se recorda. Apenas soube por pessoas da família e pelos jornaisqueera acusada de ter assassinado o marido (Laudo de exame..., 1934).

A seguir, tal como Kraepelin sugere, são consignadas informações sobre o exame psíquico da paciente. Noção de meio, tempo e lugar; confusão ou clareza de espírito; o humor em suas várias modal idades; comportamentos estranhos, tipos de fala; campo ideativo, educação, memória, juízo sobre si e sobre os outros - eram estes, basicamente, os aspectos investigados.

De suas respostas surpreen de-se desde logo a sua acentuada pobreza mental que está a patentear-se no seu reduzido vocabulário, na sua precária capacidade de perceber, de calcular, de descrever objetose animais, de compreen der pal avras abstratas, na carência de noções gerais etc. Não tem a paciente noção exata de sua situação legal, não sabendo se está processada, porque está processada, etc; pedindo-nos ajuda, cada vez que a examinávamos, para a deixarmossair. Não conhecebem as cédulas do nosso dinheiro, diz ter 16 an os quan do tem 35 anos presumíveis e não tem perfeita orientação cronológica. Os seus conceitos ... são pueris. Quanto à memória, surpreen demos a existência defal has, máxime para os detal hes dos fatos. Quanto a sua capacidade para o trabal ho, acha-se, como éfácil de prever, consideravelmentelimitada por esse apoucamento intel ectual, sendo deficientea sua iniciativa para o mesmo. O seu humor é calmo, sendo a paciente um tanto humilde. Não tem alucinações nem delírios. Omissos são os seus antecedentes mórbidos hereditários e pessoais, graças a sua condição mental que não Ihe permite dar informações fidedignas (Laudo de exame... 1924).

Esta era a etapa em que se trabalhava de forma mais subjetiva, visando apreender o psiquismo do examinado. Henrique Roxo (1925, p.50-54), por exemplo, explicava minuciosamente como deveria ser o exame: o método consistiria de perguntas abertas, orientadas segundo cada caso clínico, devendo haver apenas uma orientação comum. O observador precisava exercitar a percepção einterpretação dosmais imperceptíveis detalhes. Inicialmente, a tarefa do alienista era definir o estado do paciente - calmo ou agitado, al egre ou triste. $\mathrm{O}$ tom com que o observado respondia às perguntas já poderia indicar traços degenerativos ou marcas de alucinação. A anamnese, a pesquisa sobre condições de vida, noções éticas, comportamentos sociais, bem como sobre memória, modo de falar e inteligência ficariam para o final do exame. Avaliar-se-ia em seguida o temperamento considerado resultante das condições orgânicas, base fisiológica do caráter individual, com perfis normais e anormais, dependendo da interligação entre os dados acerca da hereditariedade, anatomofisiologia e da etiologia da doença.

Para Roxo (1925, p.4), era essencial captar a simpatia do doente para que ele se abrisse e descrevesse todo o delírio. Para tanto, era necessário deixá-lo falar à vontade. Medeiros, então médico do Hospício Nacional, também recomendava não forçar nem auxiliar as respostas dos doentes, e enfatizava que a condição essencial para uma boa observação de um alienado era a confiança que este depositava no "psicólogo" (Medeiros, 1908, p.40). 
O falar poderia indicar a presença de anomalias como lalomania, hiper ou hipossemia e hiper ou hipomimia (uso de muitos/poucos gestos); parassemia e paramimia (falar com gestos contrários e extravagantes); pseudologia fantástica (prazer em mentir) e disartria (palavra entrecortada). Já o pensamento deveria ser avaliado conforme a emoção suscitada pelas perguntas, a preferência por certos temas e a aversão a outros, olhares investigadores e momentos de distração. Porém, em al guns casos - como os de melancolia -, podia ser preciso "arrancar as palavras, para se chegar a um resultado qualquer" (Medeiros, 1908, p.21). Mas Medeiros lembrava que uma pergunta bem formulada podia ter resultado "mágico" (p.21).

No tocante ao exame mental, Medeiros (1908) defendia avaliações objetivas e científicas, baseadas em instrumentos de pesquisa e tecnologias cada vez mais avançadas: avaliação do grau de atenção pelo método de Bourdon (docilidade para hipnose); avaliação da capacidade mental e do nível intelectual por meio da fala, de escritos ou da psicometria de Buccola - que pretendia medir o tempo de reação e duração dos atos psíquicos elementares e complexos, por meio do cronoscópio de Hipp ${ }^{23}$ (Roxo, 1925, p.55). “Um alienista que se limita à observação - escreve Medeiros (1908, p.32) - não consegue saber o que o seu paciente está pensando. Para isso ele necessita empregar métodos psicofisiológicos, como, por exemplo, aplicar-Iheo aparelho pneumógrafo de Marey, para perceber em sua respiração traços de excitação ou depressão".

Também eram registradas no campo Observação as informações oriundas dos exames diretos dos pacientes. Variados, tais exames objetivavam aferir, por meio de exames clínicos e laboratoriais, tanto o estado geral de saúde do sujeito como sua constituição física. Veriricava-se inicialmente a existência de doenças crônicas, como a tuberculose e a sífilis, por meio de asculta e da reação de Wassermann, respectivamente. Outros exames frequentes eram os de urina, do liquido cefalorraquidiano e de sangue.

Em seguida, ainda de acordo com as indicações de Kraepelin e das orientações de Magnan (Coffin, 2003; Engstrom, 2007), iniciavam-se as observações relativas a face, constituição física, pele, gânglios linfáticos, nariz, ouvidos, garganta, olhos, tórax, abdômen, aparelho circulatório, aparelho genitourinário. Todas as partes do corpo deviam ser examinadas de maneira a identificar estigmas físicos que sinalizassem a degeneração: deformidades cranianas, estrabismo, defeitos em dentese orel has, deformações ósseas, feminismo, membro viril excessivamente grande ou pequeno, cegueira, gaguez, surdo-mudez e até mesmo a fealdade (Rocha, 2003, p.174). Tórax, pulmões, coração, fígado, baço, estômago e intestinos deviam igualmente ser avaliados, procurando-se relacionar suas lesões às manifestações da alienação mental.

Passava-se então ao exame do sistema nervoso. O observado era submetido a exame de percussão do crânio e avaliação do sistema nervoso pelos reflexos tendinosos, cutâneos e pupilares. Depois, realizavam-se os testes antropométricos, que ao longo do tempo se diversificaram e complexaram no Hospício Nacional (Brasil, MJNI, 1903). As medidas do crânio serviriam para avaliar o desenvolvimento do córtex cerebral e estabelecer a proporção entre cabeça e corpo. A maioria dos documentos clínicos traz descrição minuciosa desses caracteres morfológicos, sendo registrados também os traços físicos indicativos de degeneração. Vejamos um exemplo: 
Indivíduo de estatura baixa, medindo $1 m 54$, de compleição física robusta. Pesa 50 quilos. ... Pela inspeção nota-se uma diferença en treo lombo direito eo esquerdo on de aquele [é] maisbaixo. Tem pêlos abundantes, bem distribuídos, tem pele bem lubrificada, panículo adiposo bem desenvolvido. Musculatura desenvolvida. Nota-se uma pequena cicatriz na face interna da coxa esquerda, e uma mancha [palavra il egível] na face externa da coxa do mesmo lado. No pênis tem várias cicatrizes de taman hos e formas variadas. Facies carregada de aspecto tristonho. Tem barba cerrada. Supercílios espessos, não confluentes na raiz do nariz. Orel has bem implantadas, sem lobos aderentes. Cabelei ra vasta e preta. Dentes em bom estado de conservação. Dados antropométricos: Curva frontoccipital 0,335; Curva biauricular 0,345; Circunferência horizontal 0,560; Diâmetro antero-posterior 0,180; Diâmetro transverso 0,165. Índicecefálico 91. Tipo em que seenquadra: Braquicéfal o [palavra ilegível]. Quanto aos exames, Reação de Wassermann: positiva; Linfocitose: positiva; Reação de Nonne: positiva; (Prontuário, 1923).

Vemos então elaborar-se, ao longo das décadas estudadas, um instrumental cada vez mais complexo e criterioso e, com ele, milhares de papeletas com histórias pessoais, modos de interpretar, diagnosticar e tratar as doenças mentais.

\section{Os relatórios do Ministério da Justiça e Negócios Interiores}

Para compreen dermos o cotidiano dos pacientes no Hospício Nacional percebemos que seria necessário obter mais informações sobre os espaços físicos em que eram internados e os percursos desses indivíduos no âmbito da instituição. Além disso, queríamos conhecer melhor os responsáveis pelas seções e articular suas práticas aos artigos que escreviam, de modo a identificar suas linhas teóricas, o uso que faziam das terapêuticas disponíveis etc.

Os relatórios anuai $\mathrm{s}^{24}$ enviados pelo diretor da Assistência a Alienados ao MJNI, nos proporcionaram dados sobre instalações físicas, reformas feitas no hospício, médicos que lá trabal havam, hierarquia dos vários profissionais, queixas e problemas destacados pela direção e, ainda, a atenção que o governo dava às suas demandas. No período estudado lembramos - Juliano Moreira era o diretor do Hospício Nacional de Alienados e também diretor geral da Assistência a Alienados, sendo, portanto, o autor dos relatórios enviados ao Ministério.

Os relatórios constam de uma introdução do ministro da Justiça e Negócios Interiores, informações do chefe da Assistência a Alienados, do diretor do Hospital Nacional de Alienados, dos chefes das diversas seções do Hospício Nacional (Cirurgia, Farmácia, Clinoterapia etc.), dos diretores das colônias (Ilha do Governador, Jacarepaguá e Engenho de Dentro) e dos encarregados das comissões administrativas ad hoc, constituídas para avaliar a situação da Assistência. ${ }^{25}$

\section{Sobre a forma dos relatórios}

A estrutura dos relatórios da Assistência a Alienados, no período analisado, é composta de duas partes: na primeira, o diretor da Assistência descreve o Hospício Nacional; na segunda, estão as informações sobre as outras instituições. Essa estrutura, por si, já revela a importância que tinha o Hospício Nacional de Alienados para o projeto cientificizante do Estado. 
Alguns assuntos são frequentes nos relatórios, como a necessidade de reformas na infraestrutura asilar e a prestação de contas das mudanças realizadas. No que diz respeito aos internos, quase todos os relatórios trazem quadros estatísticos com o fluxo de pacientes, bem como percentuais de diagnósticos e doenças.

Encontramos, por vezes, a descrição dos pavilhões e seções, os nomes de funcionários e sua movimentação - licenças médicas, nomeações para cargos, viagens, salários - (relatórios de 1901 a 1919). Há ainda informações esparsas sobre participação deles em congressos no Brasil e no exterior (relatórios de 1905, 1906 e 1913). Os relatórios também mencionam al terações nas leis que regiam a assistência (relatórios de 1900, 1901, 1902, 1903, 1904 e 1907) e controvérsias entre autoridades a respeito de sua aplicação (relatórios de 1900 e 1902).

Entre os relatórios analisados, destacamos os anos de 1902, 1904 e 1905, cujos anexos expõem questões importantes como conflitos entre o Pavilhão de Observação e a diretoria do hospício e a inauguração de um setor dedicado a crianças.

O anexo do relatório de 1902 intitula-se "Relatório da Comissão de Inquérito sobre as condições da Assistência a Alienados no Hospício Nacional e colônias da Ilha do Governador". ${ }^{26}$ Tratava das péssimas condições do Hospício, enfatizando a lotação excedente, a mistura entre pensionistas e indigentes e a "promiscuidade" entre adultos e crianças. ${ }^{27}$ A Comissão constatou que tampouco havia divisão entre espécies nosológicas, quer psiquiátricas ou de natureza geral. Além disso, criticava o tempo ocioso dos enfermos no asilo e a falta de higiene e organização, ressaltando os conflitos entre o Pavilhão de Observação e a diretoria do Hospício.

O relatório de 1902 refere-se à nomeação de Juliano Moreira para o cargo de diretor do Hospício Nacional e à destinação de verbas para as mudanças estruturais por que passaria a instituição em sua gestão. O relatório descrevia a ampliação do Pavilhão de Observação, que manteve sua autonomia em relação ao Hospício Nacional e sua ligação com a Faculdade de Medicina do Rio de Janeiro.

Como consequência da Comissão de Inquérito e do ingresso de Juliano Moreira, houve a inauguração do Pavilhão Bourneville (destinado às crianças), relatada no relatório publicado em 1903. Outras mudanças foram a instalação dos serviços fotográficos, oftalmológicos, odontológicos e do gabinete antropométrico ${ }^{28}$, bem como se reportava a organização das oficinas de costura e a melhora do laboratório de histoquímica. ${ }^{29}$

O relatório referente a 1904 também possui anexo, intitulado "Relatório do Diretor Interino do Hospício Nacional de Alienados". Escrito por Afrânio Peixoto , tratava em detal hes das mudan ças empreen didas nas seções, os tratamentos, as doenças mais frequentes, a arquitetura, as leis etc. ${ }^{30}$ Aspecto ressaltado é a inauguração, em 3 de abril de 1905, do Serviço Cirúrgico e do Pavilhão para Moléstias Infecciosas Intercorrentes. Foram edificados, então, o Pavilhão para Epiléticos Tranquilos ou Semitranquilos e o Pavilhão Seabra, com algumas oficinas. Instalou-se ademais uma biblioteca para funcionários e outra para enfermos da seção Calmeil, seção masculina para pensionistas.

O relatório concernente ao ano de 1905 possui três anexos. O maior foi escrito pelo diretor do Hospício, Juliano Moreira, que também relata detal hadamente a situação e as mudanças no Hospício Nacional. Os outros dois são os "Relatórios dos membros das comissões inspetoras dos estabelecimentos de alienados em diversos estados" e o "Relatório 
da Comissão Inspetora da Assistência a Alienados no Distrito Federal", dedicado aos estabelecimentos particulares existentes na capital do país. O anexo do diretor do Hospício menciona, pela primeira vez, os Pavilhões Guislain e Griesinger, ambos para epiléticos (o primeiro para homens, o segundo para mulheres, provavelmente o mesmo referido no relatório anterior, mas sem o nome da seção), o Laboratório Anatomopatológico, aludindo também à criação de uma sala de leituras na seção Pinel, seção masculina de não pagantes, ou indigentes, como eram denominados esses pacientes nos relatórios. ${ }^{31}$

Desde 1900 são constantes as reclamações de superlotação do Hospício, o que passa a estender-se às colônias a partir de 1903. O diretor defendia a criação de novas colônias justamente para desafogar o Hospício Nacional. ${ }^{32}$ As seções mais lotadas eram a Pinel e a Esquirol (demulheresnão pagantes), querepetidamente atingiam o dobro da sua capacidade, que era de 250 pessoas. ${ }^{33}$

A doença que mais óbitos causava no Hospício Nacional era a tuberculose, e por isso com frequência o diretor pedia um pavilhão destinado a abrigar esses doentes. ${ }^{34}$ Os alcoólatras representavam o maior número de reincidentes e também o maior número de diagnósticos. Apesar disso, os relatórios nos informam sobre a presença de "muita comida, vinho do porto, vinho virgem e cerveja" no Hospício Nacional, o que foi criticado pela comissão de 1902 (Brasil, MJNI, 1902, p.22). Depois da posse de Juliano Moreira, a referência a esses produtos desaparece dos relatórios. Entretanto, Henrique Roxo (1910) comenta que "no Hospício é mais fácil encontrar al guém que te dê o que beber do que um pão" (p.410), a demonstrar a permanência de bebidas no interior da instituição.

Entre 1908 e 1928, os relatórios ficam mais padronizados, com estruturas semel hantes. Iniciam pelo movimento de internos, em seguida dissertam sobre cada seção e serviço e, por último, tratam do movimento de funcionários (licenças, nomeações, substituições). Por fim, há os relatos sobre as colônias. Tão parecidos são, que os de 1911 e 1912 apresentam os mesmos números para os serviços de eletricidade médica e de odontologia, o que deixa margem a dúvidas quanto à veracidade dos dados.

Os serviços terapêuticos mais citados são o gabinete da el etroterapia ${ }^{35}$, a clinoterapia ${ }^{36}$, os serviços cinesioterápicos ${ }^{37}$ e hidroterápicos ou de bal neoterapia ${ }^{38}$, constituindo este último, segundo o relatório de 1910, um dos principais elementos de cura de que dispõe o alienista.

\section{Conteúdo da base de dados}

A análise dos relatórios deu origem a uma base de dados com informações sobre o Hospício Nacional de Alienados e o Pavilhão de Observação. A base trata de cada um dos relatórios anuais analisados e apresenta informações sobre os profissionais das instituições (ministro; diretor; médicos e outros profissionais). No que se refere aos pacientes, a base reúne informações sobre o número de óbitos de internos e os diagnósticos, bem como as estatísticas referentes ao número de pacientes do Distrito Federal e do estado do Rio de Janeiro, estrangeiros e de outros estados. Quanto à estrutura física, destacamos na base informações sobre reformas e mel horas sofridas ao longo do período estudado, bem como informações sobre o patrimônio do Hospício Nacional. No tocante à Assistência a Alienados, 
são discriminadas outras instituições e serviços; normas ministeriais, leis, decretos, portarias, estatutos e afins (com links para cada um deles). Finalmente, ressaltamos disputas e controvérsias internas ou externas relatadas nos relatórios; idas de médicos a congressos e outras atividades no exterior; visitas de médicos estrangeiros no Hospício; e, finalmente, congressos organizados pelos profissionais da instituição.

\section{Hospício Nacional de Alienados em imagens: a reforma Juliano Moreira e o estandarte da psiquiatria no Brasil}

\section{A reforma de 1904}

O início da gestão de Juliano Moreira, em 1903, marcou uma inflexão na estrutura para tratamento dos asilados no Hospício Nacional de Alienados, tratado até então como "casa para detenção de loucos, onde não há tratamento conveniente, nem disciplina, nem fiscalização" (Relatório técnico..., 1903). À alegada ruína material e moral do Hospício contrapôs-se uma ampla reforma, viabilizada pela reorganização da Assistência a Alienados em 1903 (Brasil, 22 dez. 1903), que incorporou diversas das solicitações feitas por Juliano Moreira em ofício de 16 de julho daquele ano. Concluídas em 1904, as obras foram relatadas e justificadas nos relatórios ministeriais subsequentes (1904 e 1905). A planta da Figura 1 distingue, em preto, as novas construções e em hachuras, as edificações antigas também reformadas.

Além de relatar as vantagens das novas instalações do Hospício e seus serviços, o relatório apresenta cinquenta fotografias ${ }^{39}$, como registro inconteste das modificações realizadas. As imagen s refletem não apenas as modernizações do espaço asilar, mas igual mentepacientes em atividades terapêuticas ou a circular pelo asilo. Para além do efeito comprobativo que expressam e que se coaduna com os objetivos para o qual foram primariamente produzidas, as fotografias do Hospício Nacional revelam alguns elementos do cotidiano de uma instituição psiquiátrica no início do século XX. A opção por utilizar majoritariamente registros construídos de forma elaborada, com uma representação harmônica do ambiente, dos pacientes, dos médicos e dos equipamentos, permite entrever tanto o que lá está visivelmente representado quanto as ausências igualmente significativas.

O lugar dos insanos, dos epilépticos, dos loucos perigosos, dos imundos, das loucas, das histéricas, dos dementes, dos desasseiados, dos idiotas e dos imbecis, conforme denominação correntemente utilizada nesse período, não é o mesmo lugar retratado nas imagens. Esses pacientes aparecem circunstancialmente, porém sempre de forma ordeira, cordata e participativa. De fato, em algumas das imagens, o Hospício se assemelharia a uma casa de repouso, com lazer e exercícios. As patologias, os sintomas e seus diagnósticos, motivo pelo qual aqueles indivíduos ali foram internados, não estão representados nas imagens. O espaço físico edificado e reformado na gestão de Juliano Moreira, retratado em toda a sua assepsia e ordenamento, é o lugar da ciência psiquiátrica, e não o repositório de doentes que as constantes queixas de superlotação mencionavam.

Segundo Susan Sontag (2005), a fotografia é um instrumento de poder. O registro de um evento ou circunstância cristaliza um instante no tempo, condensando importância e valor específicos ao episódio enquadrado (Sontag, 2004; Kossoy, 2001). As imagens das reformas 


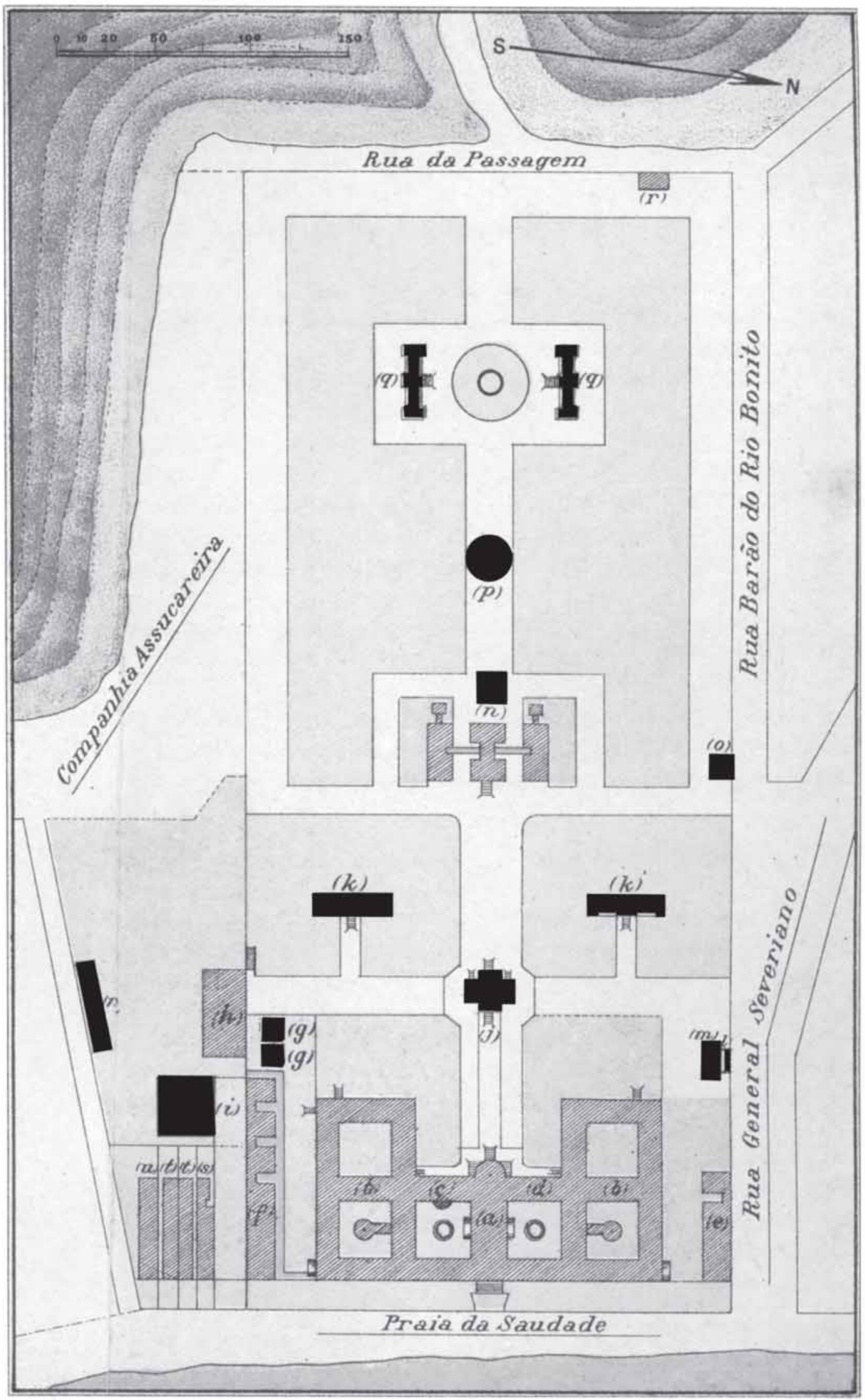

Figura 1: Planta do Hospício Nacional de Alienados (Brasil, MJNI, 1904-1905, Anexo) 
do Hospício Nacional podem ser interpretadas, portanto, como a demonstração desse modelo científico moderno, posto em prática no tratamento psiquiátrico por Juliano Moreira. ${ }^{40}$

Assim, uma análise pormenorizada das fotografias do Hospício permite relacionar a conjuntura em que elas foram feitas a um exame dos principais elementos constitutivos de sua produção (assunto/tema, fotógrafo e tecnologia empregada). Conforme indicou o historiador Ul piano Bezerra de Menezes (2003), o empirismo das imagens não está somente nas informações que elas apresentam, mas também na forma como foram visualmente elaboradas. Tal perspectiva permitenos apontar a forte vinculação ideológica com o ideal de progresso da ciência médica e psiquiátrica. É o que vemos nas imagens aqui reproduzidas.

\section{Imagens do Hospício}

Entreas diversas modificações na estrutura do asilo, os relatórios de 1904 e 1905 ressaltam as novas instalações da cozinha (Figura 2), da lavanderia e do necrotério, demonstrando o cuidado na preparação de alimentos, bem como o asseio e a higiene que imperam no Hospício Nacional. A cozinha fora edificada entre o edifício principal e o Pavilhão de Observação, e nela instalado um sistema a vapor, com o objetivo de facilitar o preparo dos alimentos. Também foram adquiridas quatro duplas de marmitas, grandes panelas de ferro fundido apoiadas em uma base que girava em torno de um eixo (Figura 3).

Para viabilizar o pleno funcionamento dos novos serviços, instalou-se uma usina de el etricidade, destinada a fornecer energia ao Hospício durante a noitee, para al guns serviços, durante o dia. Foi instalada ainda, em sala própria, a Biblioteca Médica, e reformada a Biblioteca dos Enfermos, com publicações escolhidas pessoalmente pelo diretor da instituição.

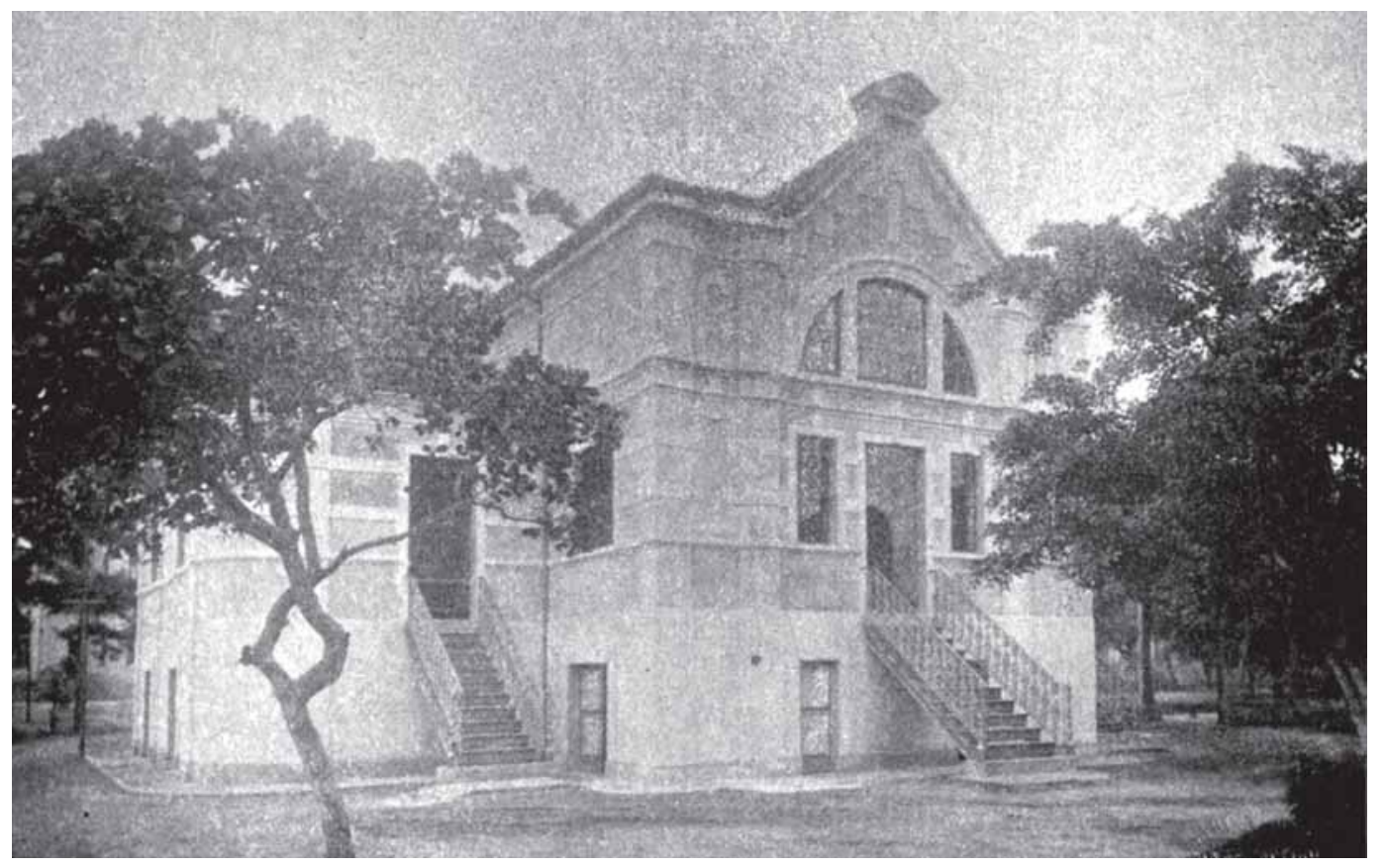

Figura 2: Fachada da cozinha do Hospício Nacional de Alienados (Brasil, MJNI, 1904-1905, Anexo). 


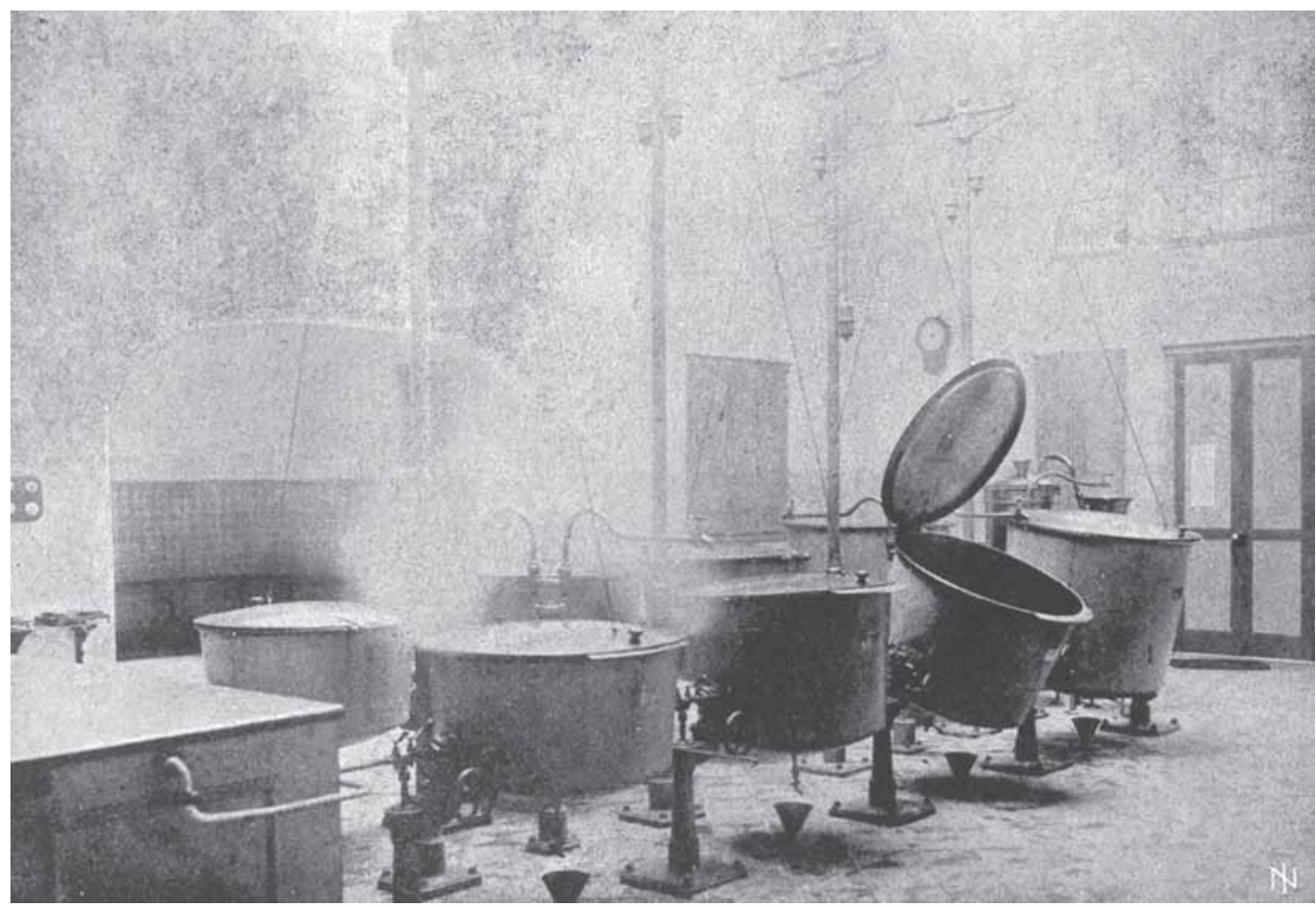

Figura 3: Marmitas da cozinha a vapor (Brasil, MJNI, 1904-1905, Anexo)

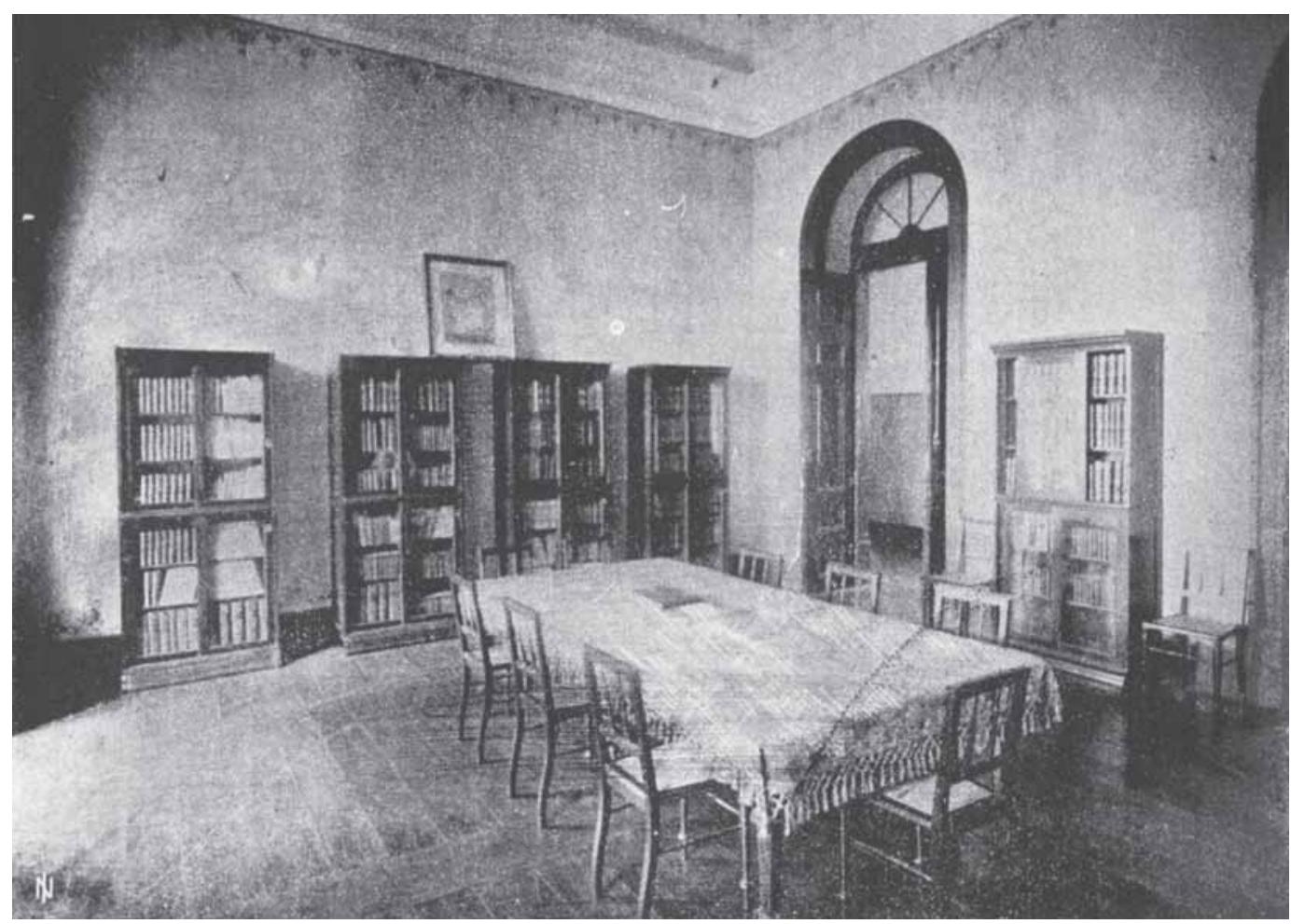

Figura 4: Biblioteca (Brasil, MJNI, 1904-1905, Anexo) 
Para acabar com os problemas que haviam sido denunciados pelas comissões anteriores, foram edificados cinco novos pavilhões: para crianças, para epilépticos e para portadores de doenças infecciosas intercorrentes - estes últimos divididos em alas para homens e mulheres. Quando se fez o registro visual das reformas, os pavilhões dedicados às moléstias infecciosas ainda não tinham sido inaugurados. Os destinados a epilépticos tranquilos ou semitranquilos já estavam funcionando (Figura 5). Para estes foram adquiridas camas especiais, ladeadas por tábuas de madeira que preveniam contra a queda dos pacientes, em caso de convulsão noturna (Figura 6).

O Pavilhão-Escola Bourneville, dedicado exclusivamente a crianças, propunha-se a oferecer-Ihes tratamento especializado, distinto do ministrado aos adultos (Figura 7). Contava com uma sala com aparelhos de ginástica, curso para educação de meninos e meninas, camas apropriadas e um jardim geométrico, que tinha como função propiciar aos pequenos o conhecimento de formas, relevo etc. (Figura 8).

O serviço de eletroterapia foi reformado, passando a dispor de energia elétrica para tratamentos como eletrólise, banho de luz elétrica, banho hidroelétrico, raios de Roentgen, ozonizador, radioscopia e fototerapia para o tratamento de doenças cutâneas (Figuras 9 e 10). Dispunha também de instalações para eletrodiagnóstico. Foi criado um serviço cinesioterápico, que incluía ginástica, massagem manual e elétrica e reeducação de movimentos. A farmácia passou a cuidar da formulação de preparados preferencialmente com produtos brasileiros e da importação de drogas da Europa.

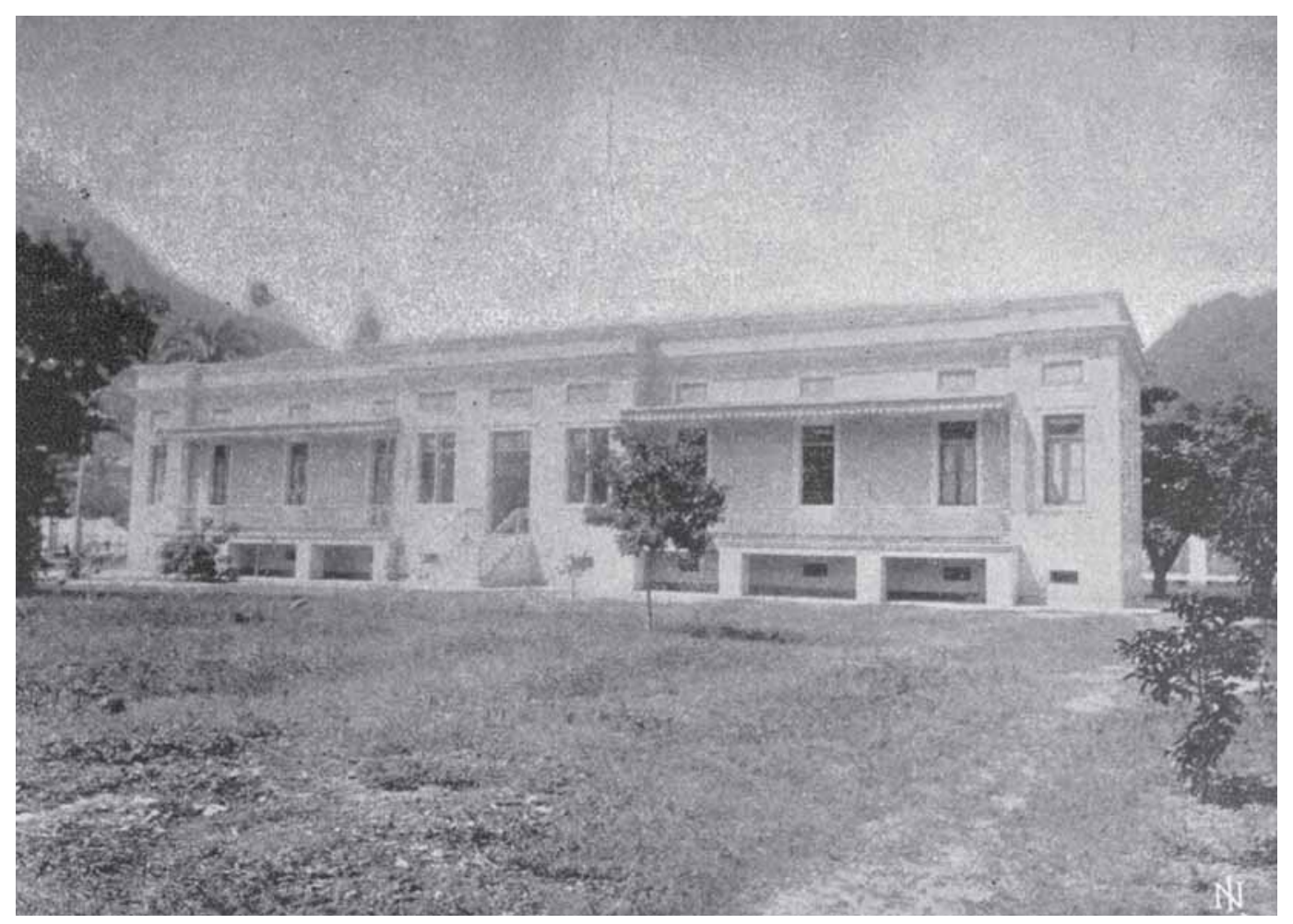

Figura 5: Pavilhão dos Epilépticos (Brasil, MJNI, 1904-1905, Anexo) 


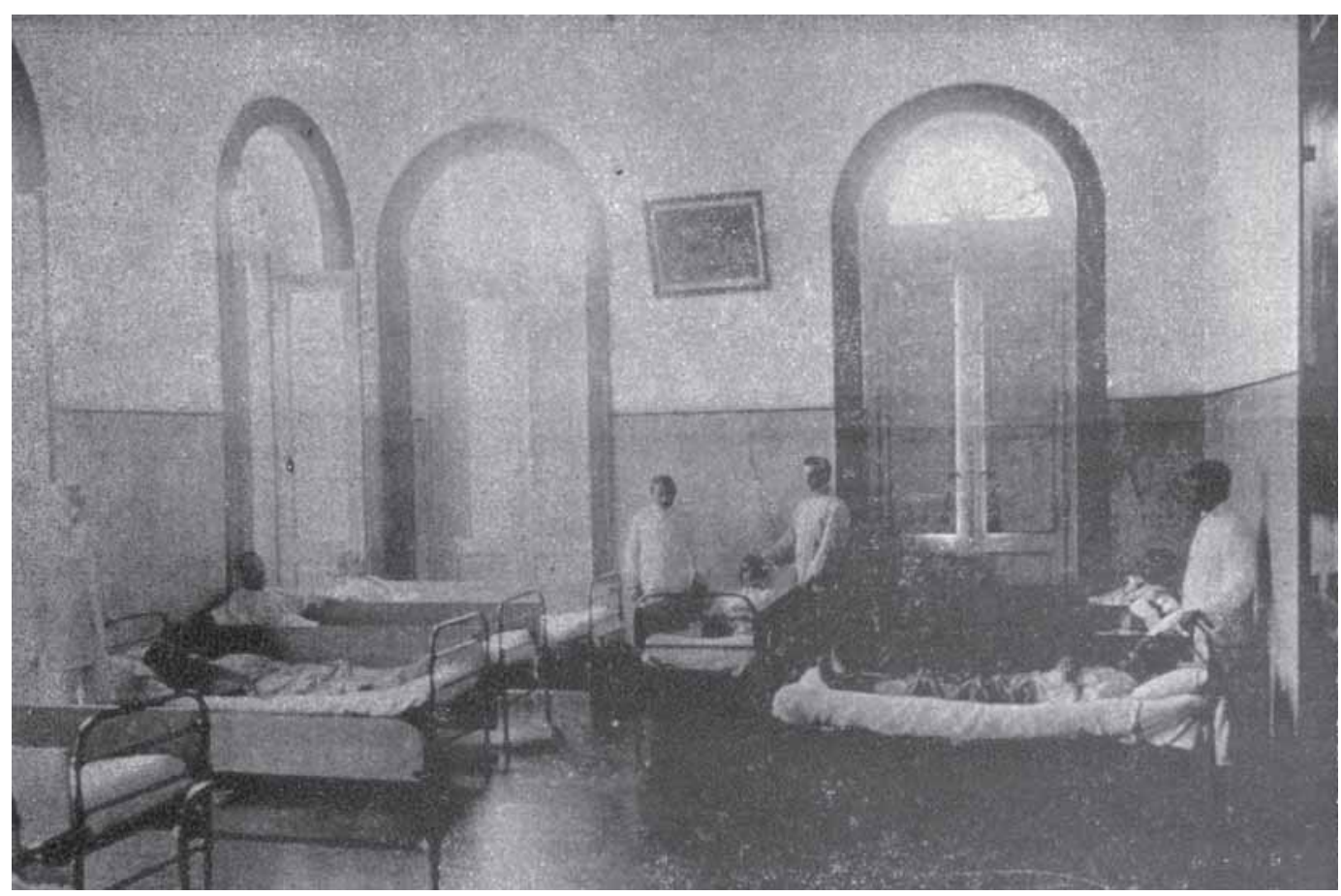

Figura 6: Dormitório de epilépticos, com camas especiais (Brasil, MJNI, 1904-1905, Anexo)

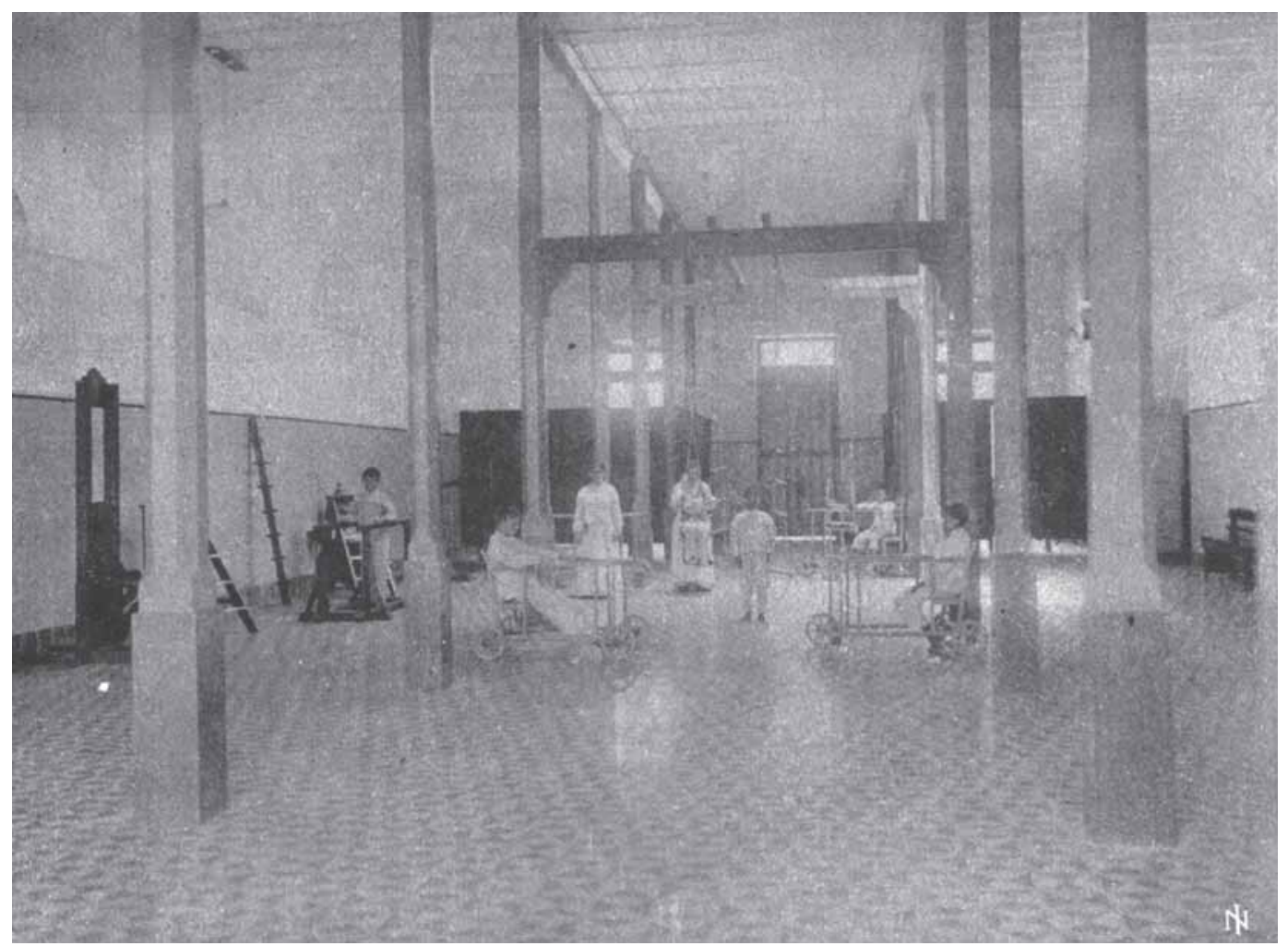

Figura 7: Sala de ginástica e recreio do Pavilhão Bourneville (Brasil, MJNI, 1904-1905, Anexo) 


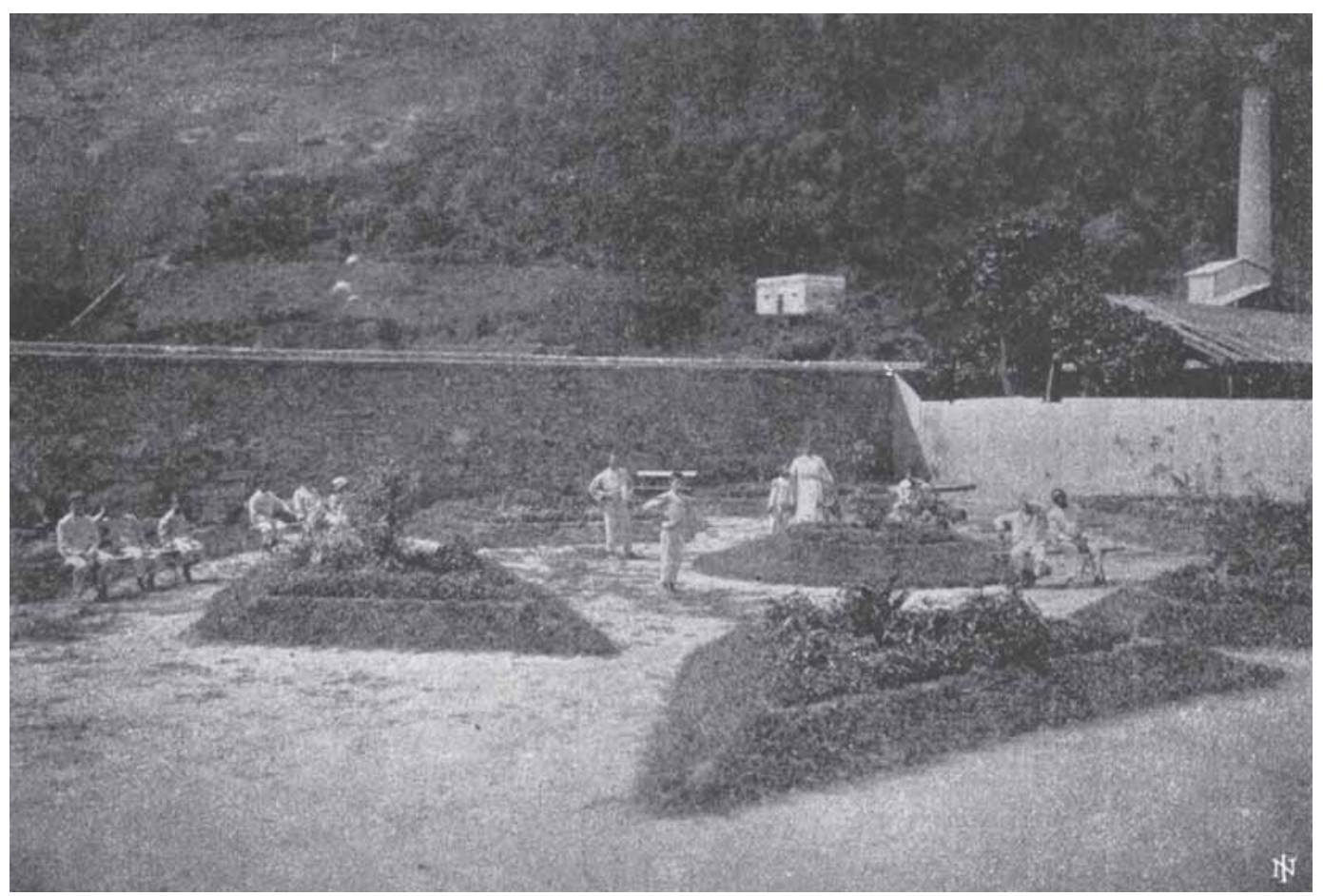

Figura 8: Jardim Geométrico do Pavilhão Bourneville (Brasil, MJNI, 1904-1905, Anexo)

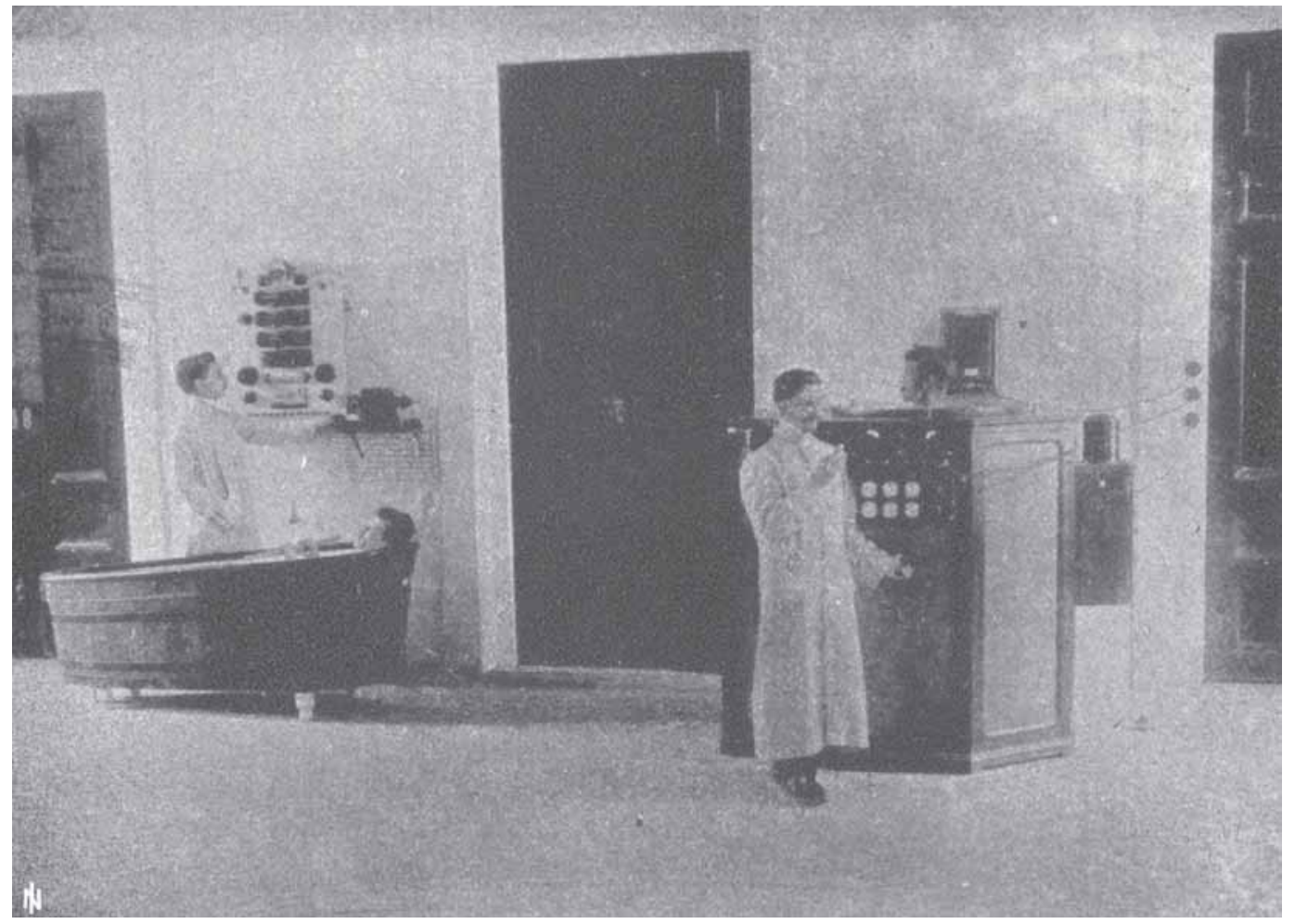

Figura 9: Sala de eletroterapia (Brasil, MJNI, 1904-1905, Anexo) 


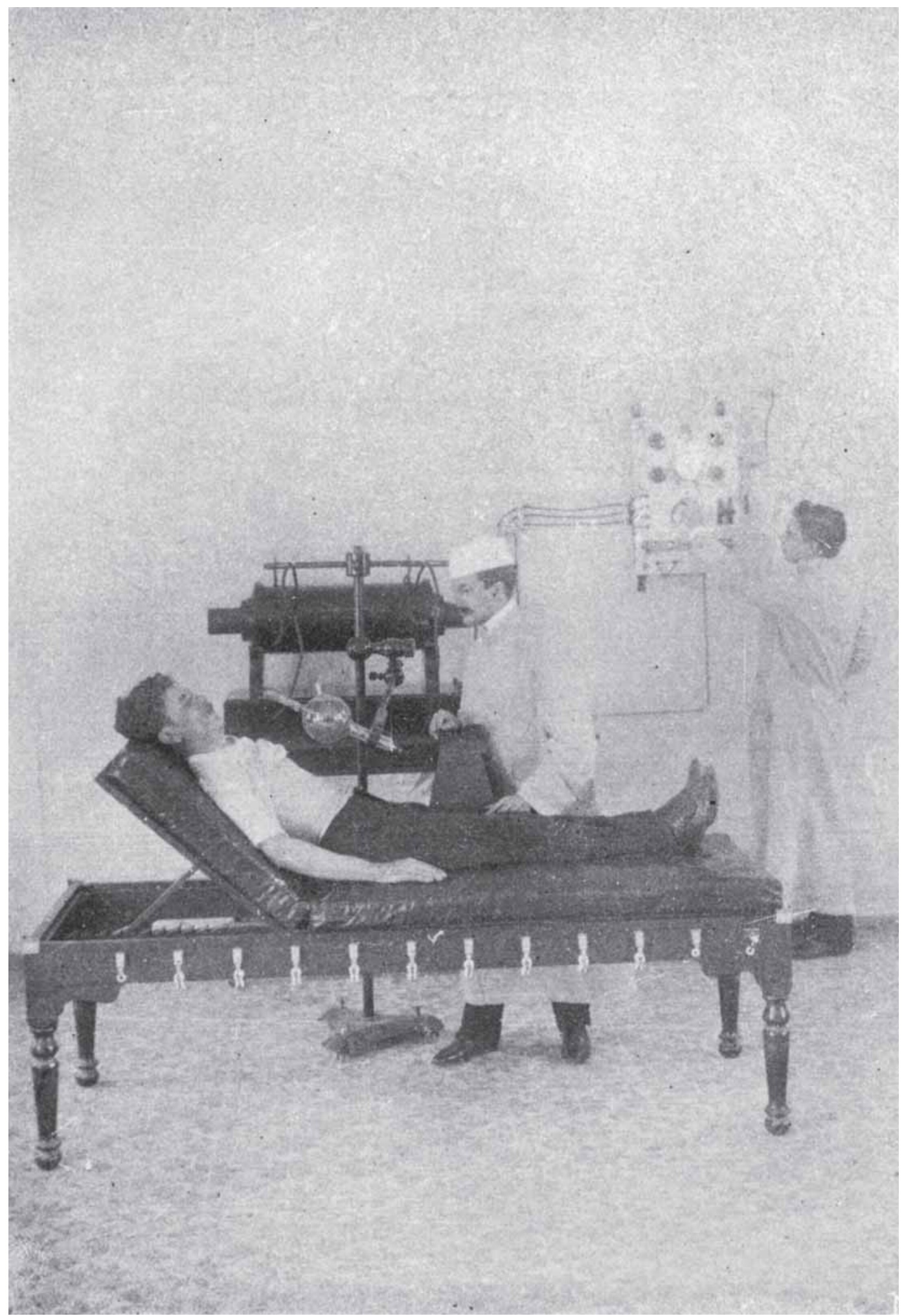

Figura 10: Gabinete de Eletricidade Médica (aplicação radioterápica) (Brasil, MJNI, 1904-1905, Anexo) 
Nos pavilhões Esquirol e Morel, dedicados às mulheres, reformaram-se os serviços balneoterápicos, com instalação de novas duchas e banheiras. Em ambos foram feitas melhoras nos refeitórios. No pavilhão de mulheres indigentes (Esquirol), instalaram-se oficinas de costura, com a dupla função de atender à demanda de roupas para os internos e de ocupar as mulheres com atividades laborais (Figura 11). Para essa seção foi, também, adquirido um piano.

Os pavilhões Pinel e Calmeil, para tratamento dos homens, também tiveram melhoras nos serviços balneoterápicos e nos refeitórios. O primeiro pavilhão era o mais populoso do Hospício. Sob a administração do doutor Antonio Austregésilo, introduziram-se modificações no tratamento dado aos internos: uso obrigatório da clinoterapia; separação, em espaço à parte, dos internos delinquentes, impulsivos ou perigosos; abolição do recurso às camisas de força; instalação de uma latrina coletiva no pátio; demissão de funcionários que infligiam maus-tratos aos pacientes; e reforma dos dormitórios dos 'imundos' (Figuras 13,14 e 15).

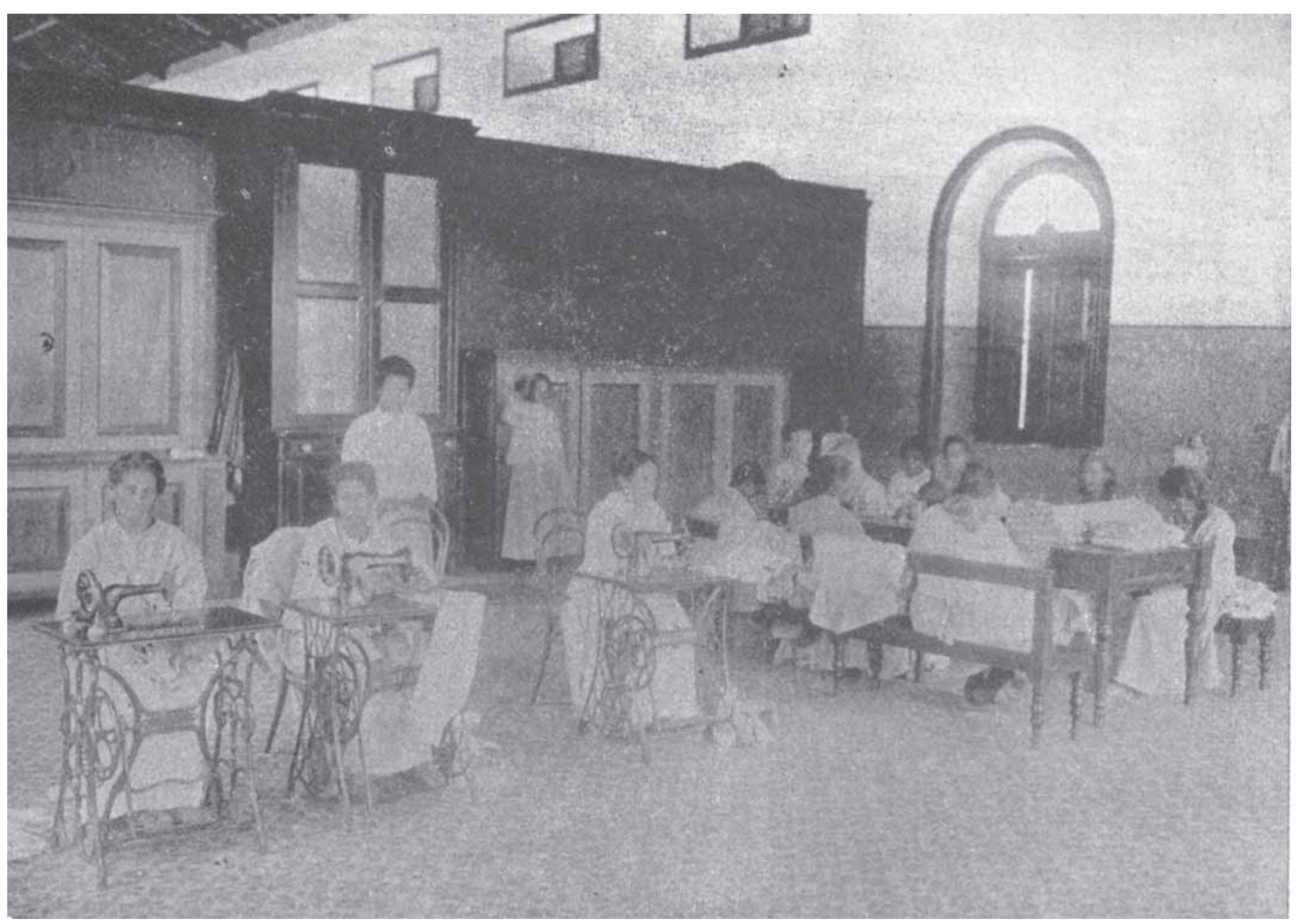

Figura 11: Sala de costura (Brasil, MJNI, 1904-1905, Anexo) 


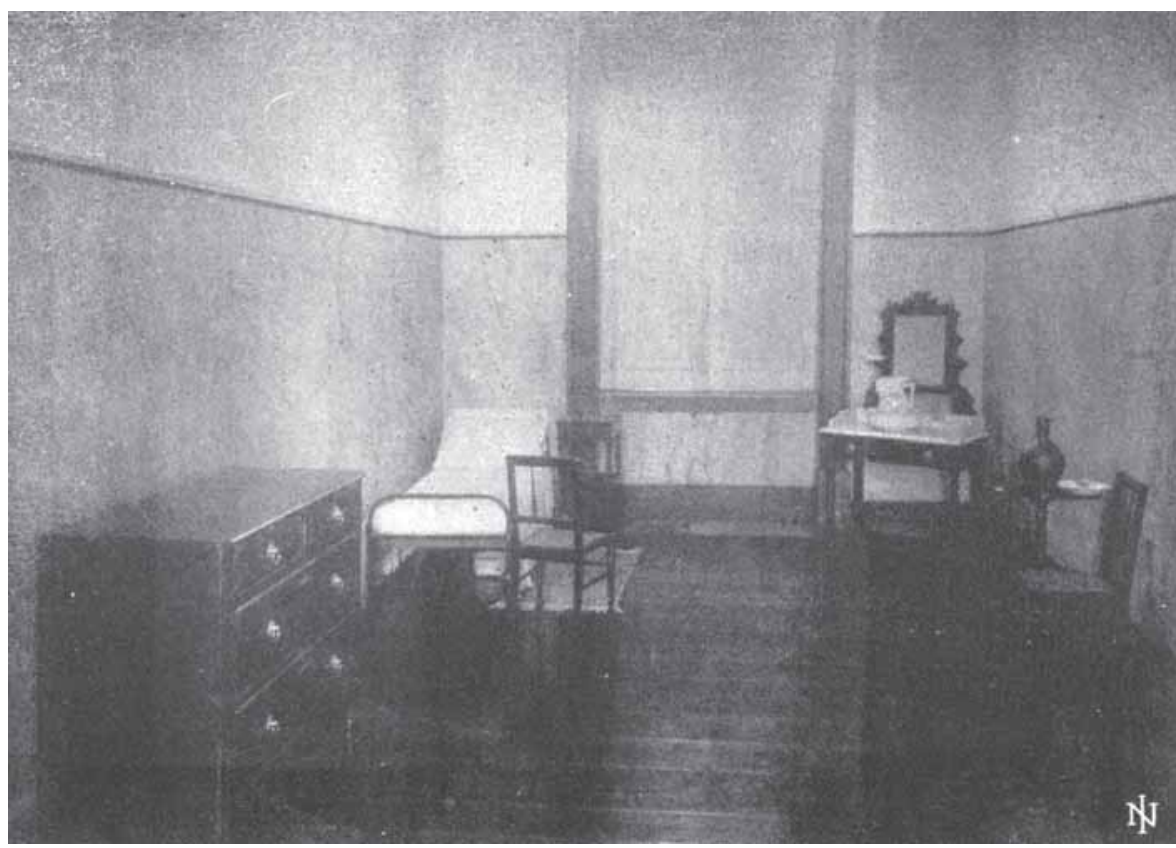

Figura 12: Um

quarto de

pensionista

(Brasil, MJNI,

1904-1905,

Anexo)

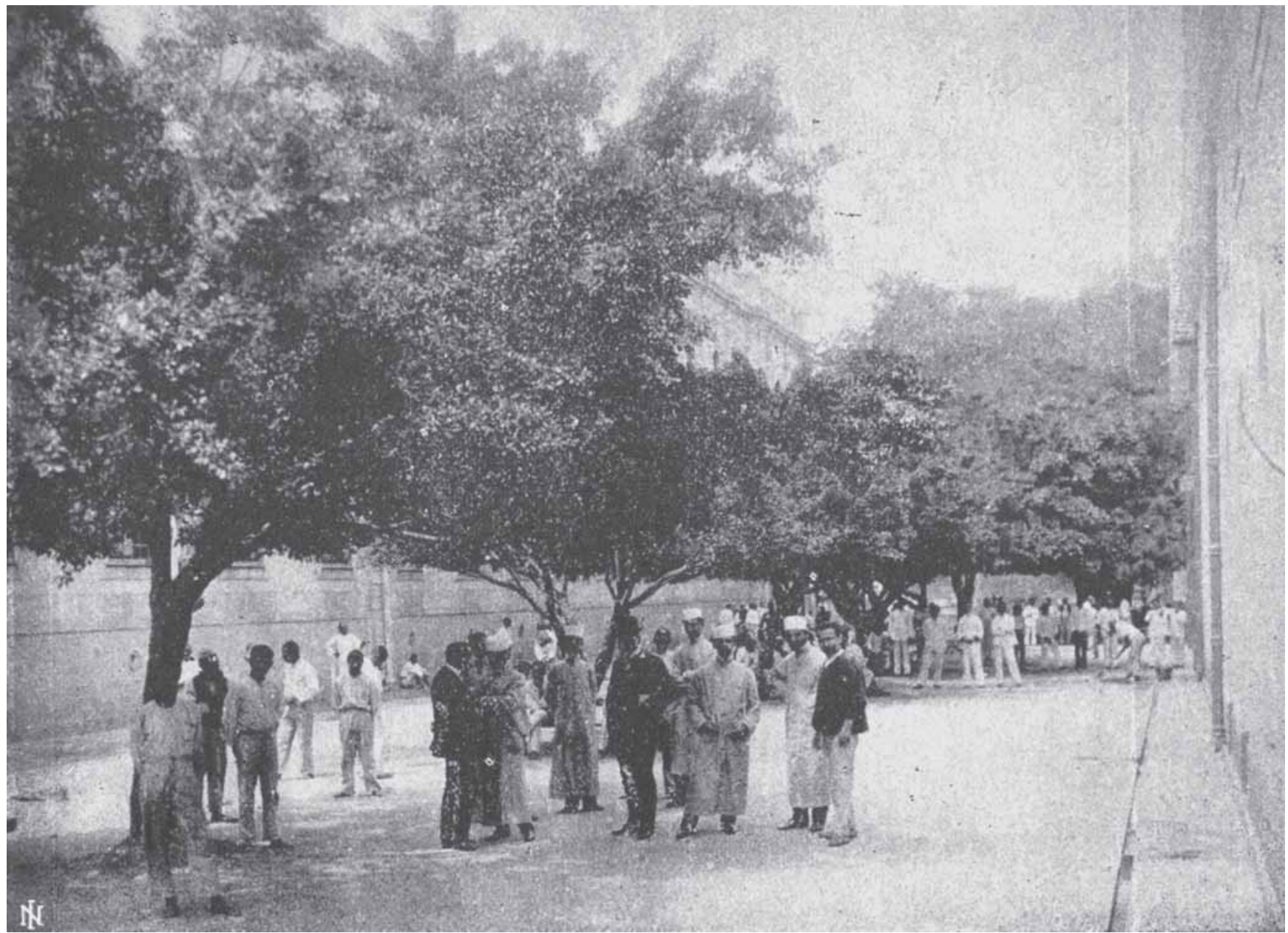

Figura 13: Pátio da seção Pinel (Brasil, MJNI, 1904-1905, Anexo) 


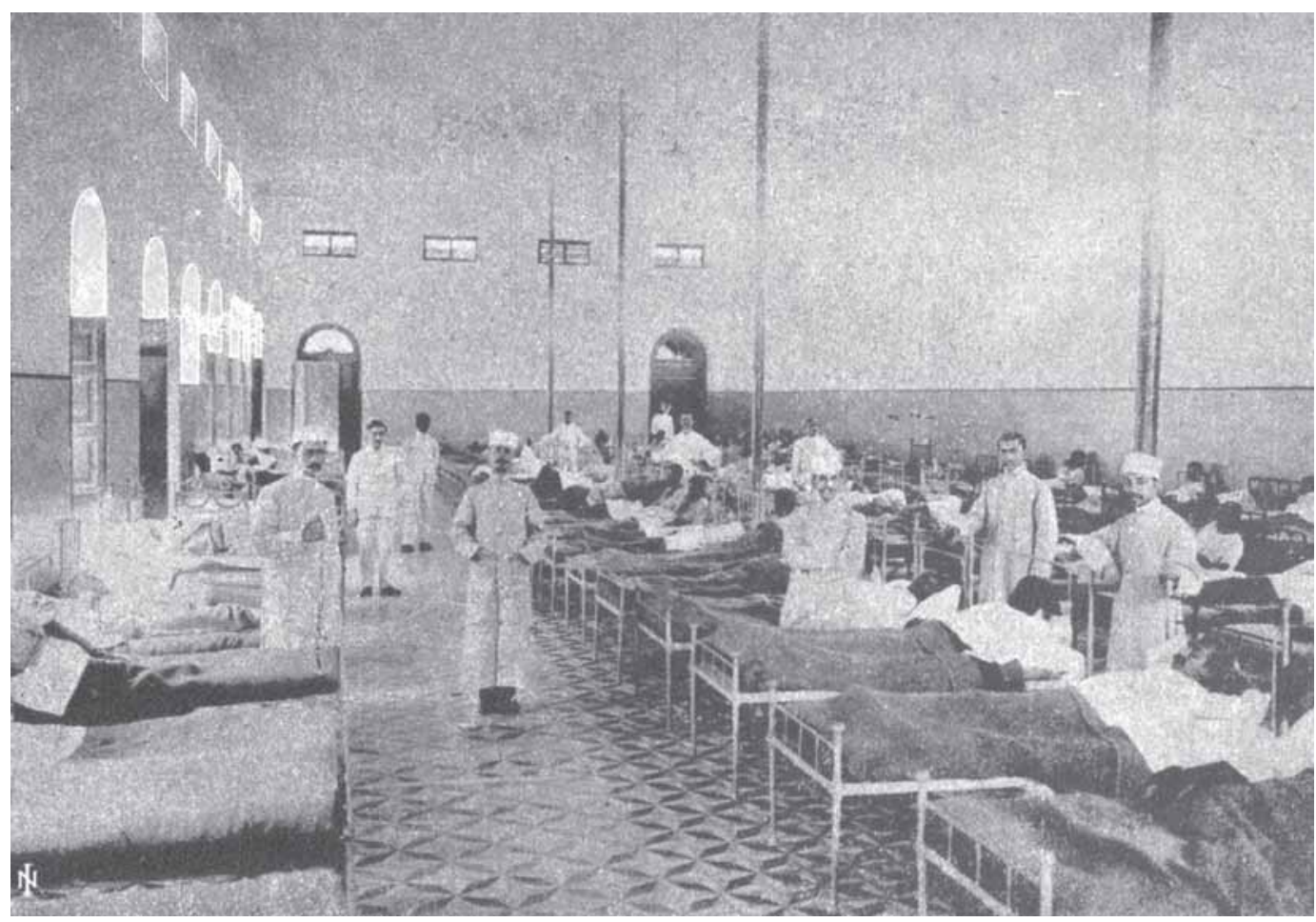

Figura 14: Pavilhão dos Desasseiados (Brasil, MJNI, 1904-1905, Anexo)

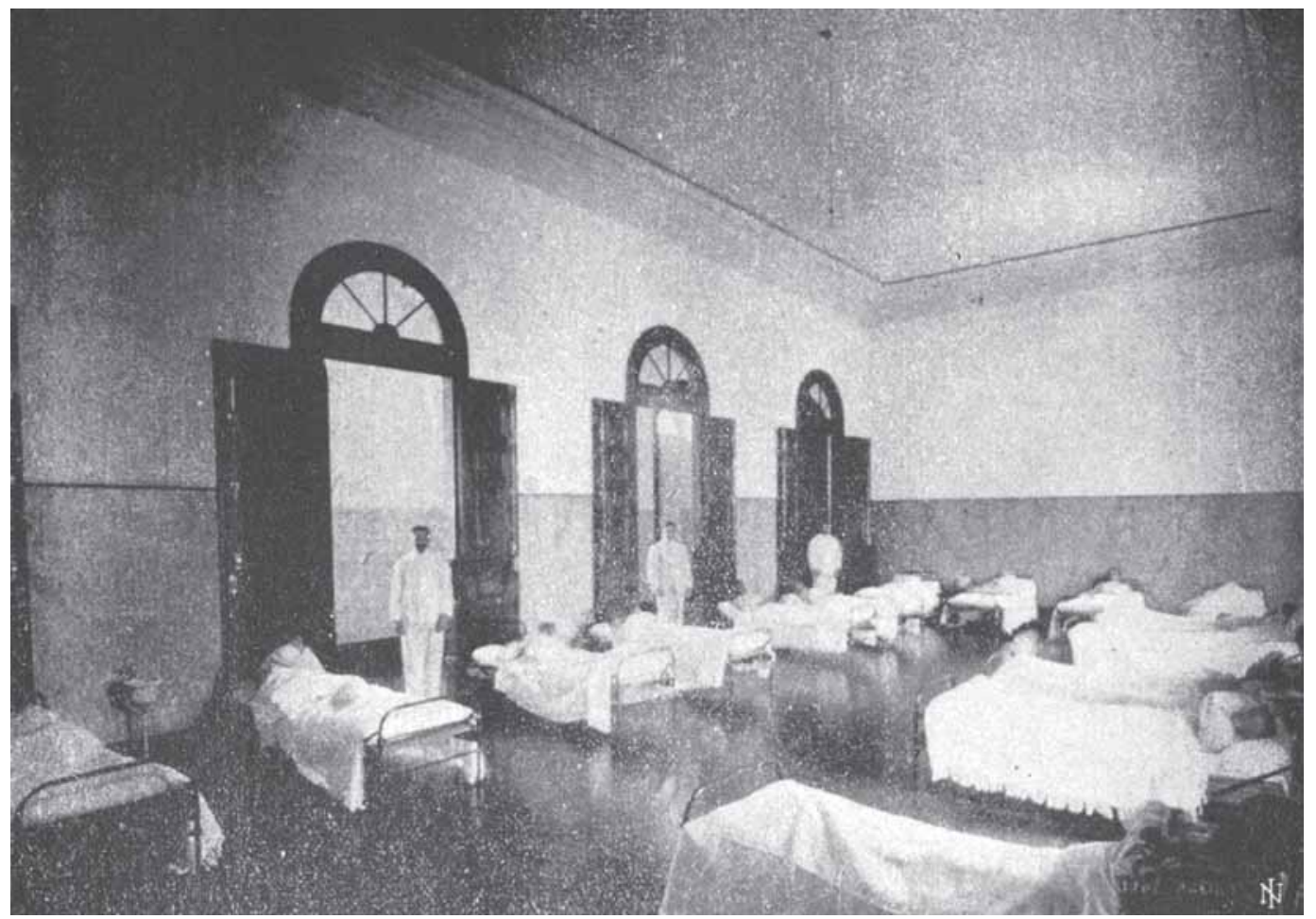

Figura 15: Sala de Clinoterapia (Brasil, MJNI, 1904-1905, Anexo) 
A Seção Calmeil, sob a administração do Dr. Afrânio Peixoto, passou a dispor de tratamento open-door, concedendo aos internos maior liberdade. Outra melhoria foi a instalação de uma sala de diversões provida de bilhar, jogo de damas, xadrez, dominó e cartas (Figura 16).

Também foi criado um Laboratório de Anatomia Patológica e Quimicoclínico, além de um Gabinete de Psicologia Experimental, e inaugurou-se um serviço cirúrgico permanente, que incluía sala de curativos, antessala operatória e sala de operações (Figura 17).

O Pavilhão de Oficinas, denominado Pavilhão Seabra em homenagem ao ministro da Justiça e Negócios Interiores, foi construído para abrigar oficinas em que internos do sexo masculino realizariam trabalhos metódicos, entendidos como ferramenta de disciplinarização e tratamento, além de oferecerem serviços de manutenção do Hospício a custo reduzido. O espaço abrigou oficinas de ferraria e bombeiro; mecânica elétrica; carpintaria e marcenaria; tipografia e encadernação; sapataria; colchoaria, vassouraria e pintura (Figura 18). Para as mulheres foram criadas oficinas de tapeçaria, fabricação de flores e costura. Às crianças destinou-se uma oficina de empalhação.

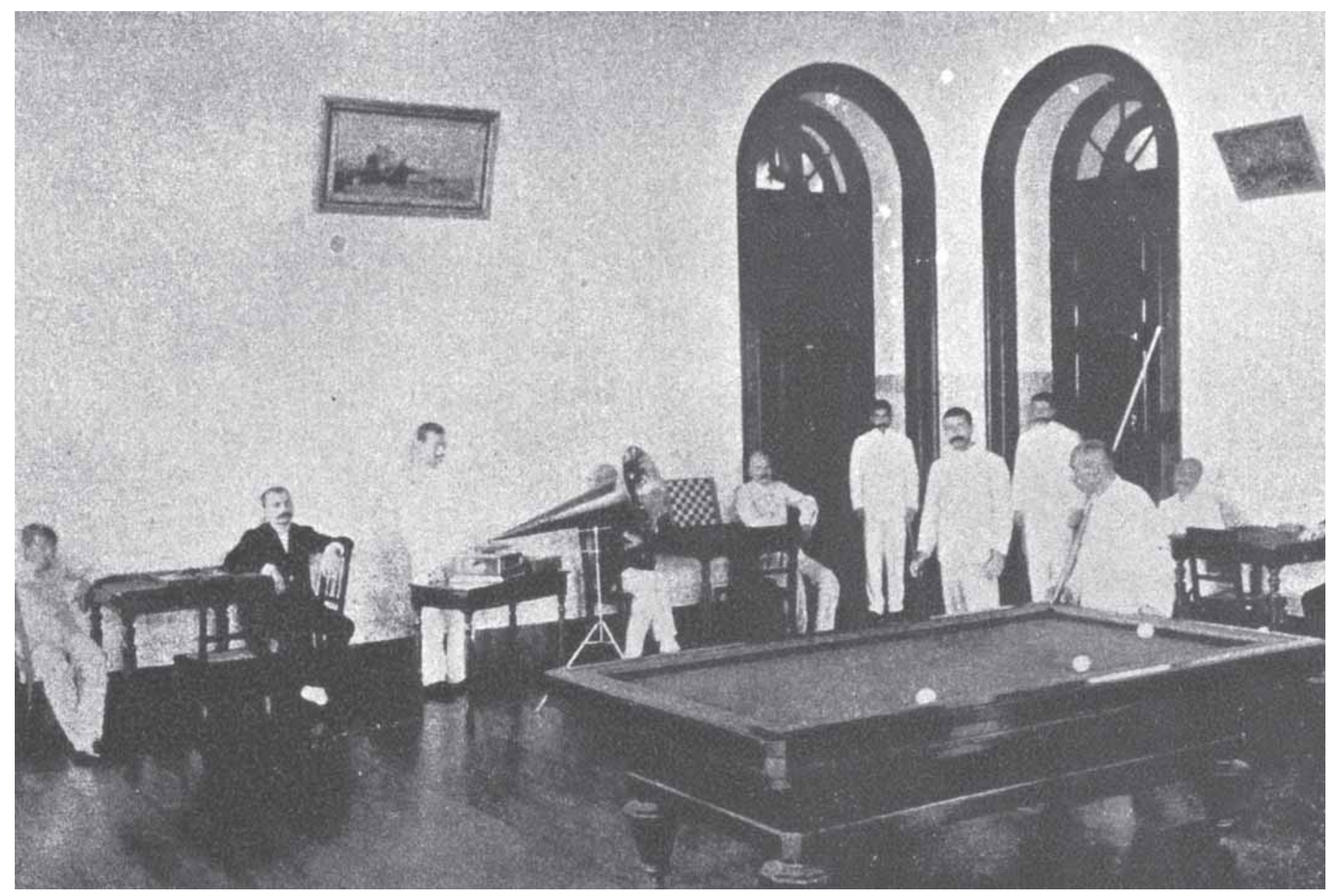

Figura 16: Sala de diversão dos enfermos (Brasil, MJNI, 1904-1905, Anexo) 
Cristiana Facchinetti et al.

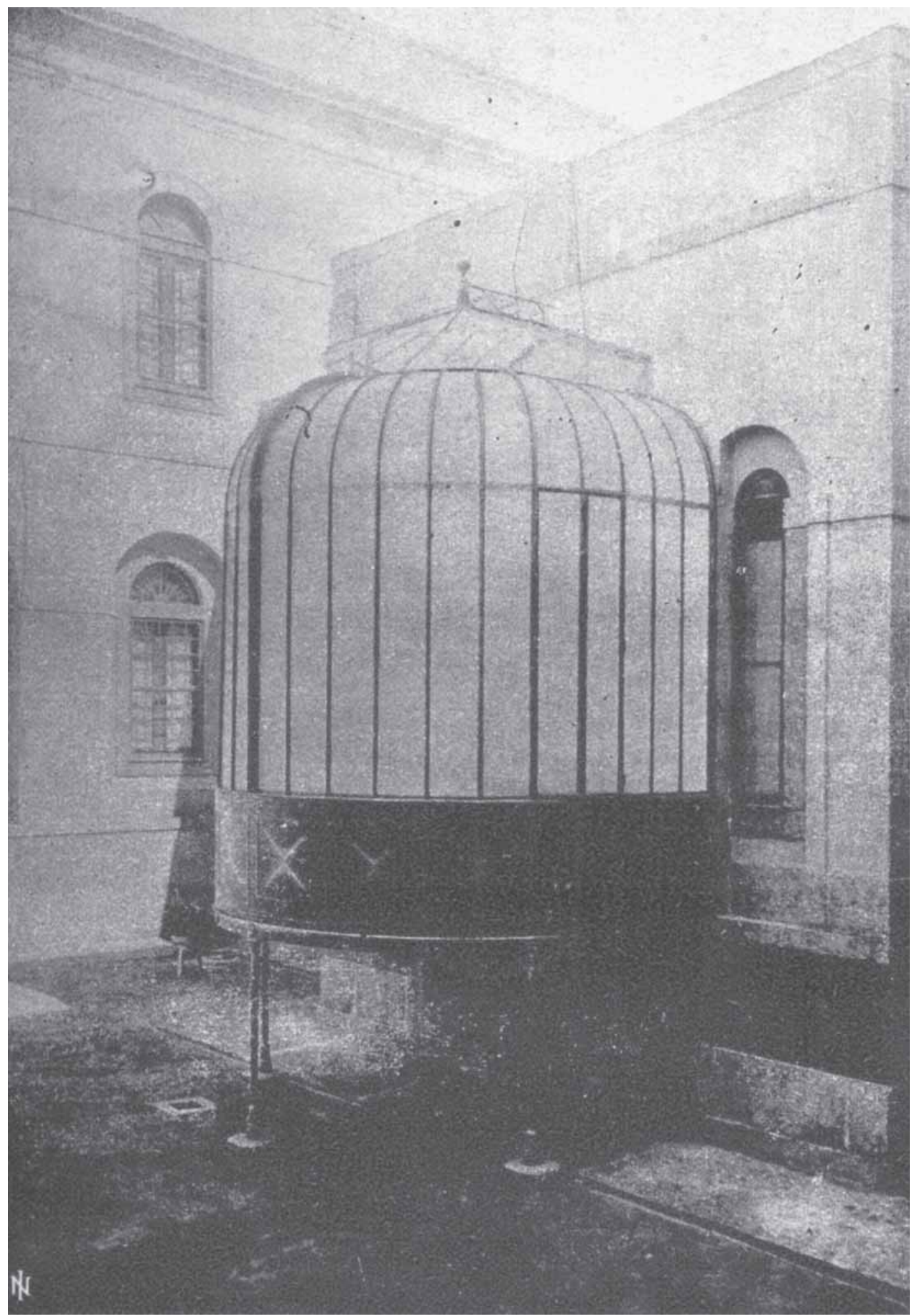

Figura 17: Fachada parcial da Seção de cirurgia. Na imagem, vê-se uma estrutura em vidro e ferro, empregada para iluminar o ambiente (Brasil, MJNI, 1904-1905, Anexo) 


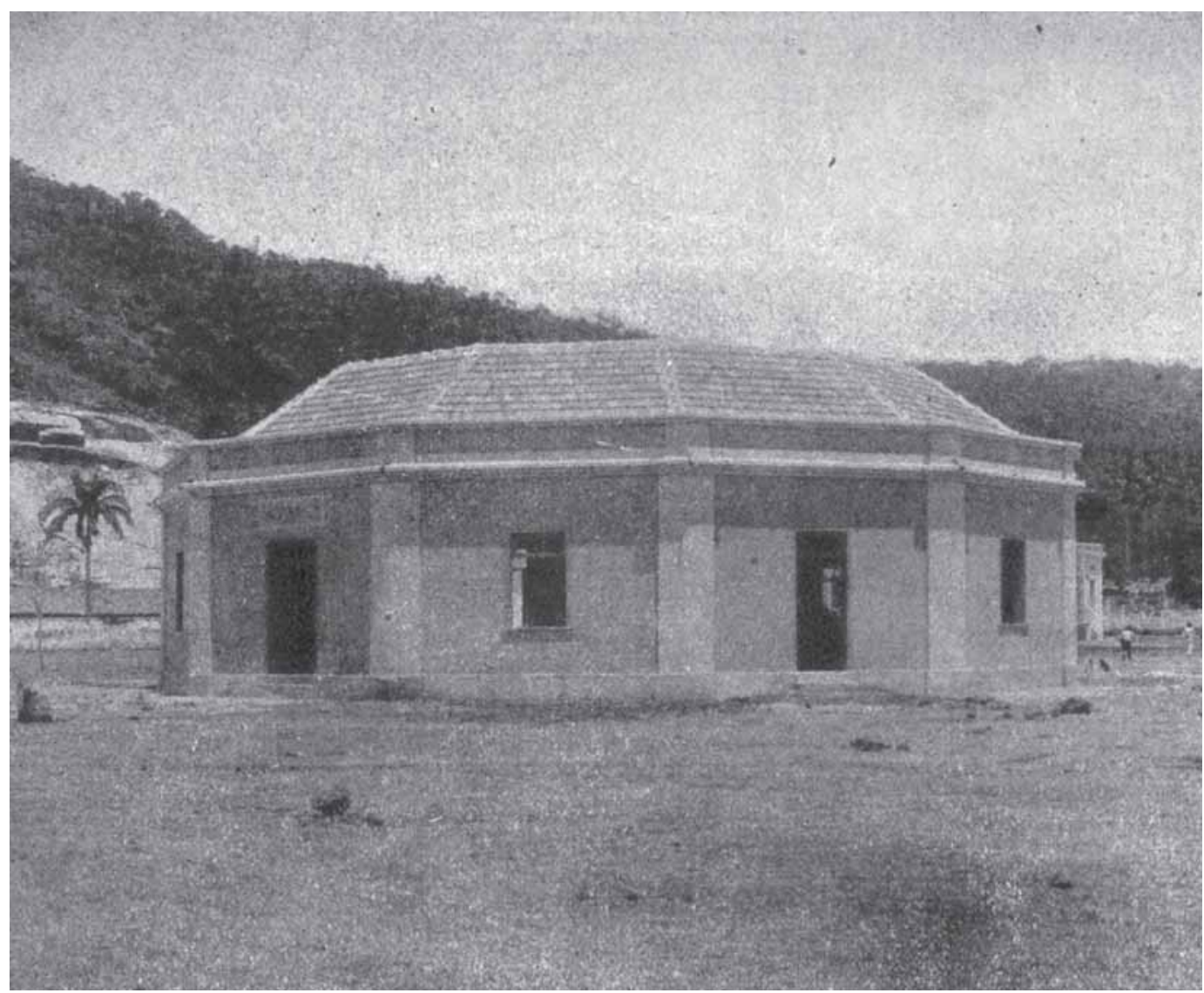

Figura 18: Pavilhão Seabra (Brasil, MJNI, 1904-1905, Anexo)

\section{O estandarte da psiquiatria brasileira}

Em 1909, alguns anos após a reforma do Hospício Nacional, a cidade do Rio de Janeiro sediou a Exposição Internacional de Higiene, por ocasião do $4^{\circ}$ Congresso Médico LatinoAmericano. Era comum à época organizar exposições públicas concomitantemente à realização de encontros, colóquios, congressos e conferências especializadas, com o propósito de apresentar ao público leigo e especializado o que de mais moderno existia no Brasil e no mundo.

Segundo Almeida (2006), apesar de dispor de poucos recursos, a Exposição Internacional de Higiene de 1909 contou com os prédios suntuosos construídos para a Exposição Nacional de 1908, em vasto terreno situado entre as praias Vermelha e da Saudade. Nos pavilhões então reutilizados, foram expostos "espécimes, artefatos, fotografias, quadros, mapas, tudo acompanhado de informações precisas e escritas em linguagem simples" (p.2), atendendo à missão de levar os princípios da higiene para a população de forma didática e acessível.

Dividida em Seção Científica, apenas com mostras de países latino-americanos, e Seção Industrial, aberta a todas as nações, a Exposição contou com a participação dos serviços brasileiros de saúde pública. Os do Rio de Janeiro ocuparam a maior parte das 43 salas 
destinadas à parte científica da exposição e entre eles incluía-se a mostra do Hospício Nacional de Alienados, constituída em grande parte pelas fotografias produzidas cinco anos antes, além de peças do Museu anatomopatológico e dos produtos advindos do Pavilhão Seabra. Ladeadas por outras representações iconográficas dos triunfos da higiene brasileira, as imagens realizavam a dupla função de situar os serviços psiquiátricos entre as demais atividades médicas exitosas e entreter o público com a demonstração da qualidade da psiquiatria brasileira.

Funcionando como material de portfólio do Hospício Nacional, a exibição pública das imagens embasava também as reiteradas solicitações de investimentos para novas reformas e ampliação dos serviços psiquiátricos nacionais. Da forma como foi utilizada na exposição, a "fotografia era, em si mesma, representação do progresso daqueles tempos" (Almeida, 2006, p.8), um estandarte da ciência psiquiátrica da época.

\section{AGRADECIMENTOS}

Agradeço aos que participaram dessa pesquisa, desde o início. Aos membros do grupo de pesquisa $\mathrm{O}$ Físico, o Mental e o Moral na História dos Saberes Médicos e Psicológicos, em especial a Ana T. Venancio e Flavio Edler, que aceitaram participar do projeto e com isso o ampliaram, aumentando seu potencial de pesquisas; aos bolsistas de iniciação científica, que ao longo dos anos colaboraram com a composição do acervo: Leonardo Bertolossi (IC-Faperj, 2003-2004); Almir M. de Souza (Pibic CNPq/Fiocruz, 20042005); Manuela H. de Freitas (IC-Faperj, 2005-2006); Jacqueline Ricarte (Bolsa Tec-Tec Faperj/Fiocruz, 2006-2007); Pedro F.N. de Muñoz (Pibic - CNPq/Fiocruz, 2006-2007; bolsa Fiocruz 2008-2010); Carlos Augusto C. Albuquerque (IC-Faperj 2007-2008); e Lennon Barcellos (IC-Faperj, 2007-2008).

\section{NOTAS}

${ }^{1}$ Sobre as diversas denominações da instituição, ver nota 1 do artigo "Arquivos Brasileiros de Psiquiatria, Neurologia e Ciências Afins: uma fonte com muita história", neste número de História, Ciências, Saúde Manguinhos. Neste artigo, será denominada Hospício Nacional.

2 Em 1907, Juliano Moreira fundou, com um grupo de alienistas do Hospício Nacional, a Sociedade Brasileira de Psiquiatria, Neurologia e Medicina Legal. Em 1908 foi organizada uma comissão nessa sociedade, composta pelos médicosJuliano Moreira, Henrique Roxo, Afrânio Peixoto, Antonio Austregésilo e Carlos Eiras, para propor uma classificação psiquiátrica que "fosse uniformemente adotada no Hospital Nacional de Alienados e nas nossas Casas de Saúde para Psicopatas" do Distrito Federal. Como resultado do trabal ho da Comissão, a Sociedade estabeleceu, em 1910, uma classificação, composta por 14 grupos diagnósticos (Roxo, 1925, p.73).

${ }^{3}$ Em relação ao recorte temporal trabalhado na pesquisa, optou-se por analisar os documentos clínicos produzidos desde a crise que destituiu três diretores do Hospício Nacional (desde 1900) e resultou na nomeação, em 1903, de Juliano Moreira como diretor dessa instituição e da Assistência a Alienados, até 1930, quando Moreira foi aposentado, após Getúlio Vargas assumir a Presidência da República. Esse recorte é justificado por considerar-se a entrada de Juliano Moreira um momento relevante para a institucionalização da psiquiatria no país. No Hospício Nacional, com apoio do governo, ele foi capaz de mobilizar novas correntes teóricas, efetuar reformas no asilo, conformar grupos e destituir resistências (Portocarrero, 2002; Engel, 2001; Venancio, 2005).

${ }^{4} \mathrm{O}$ decreto 206, de fevereiro de 1890, criou a Assistência Médica e Legal de Alienados, um mês depois de - Hospício ser desanexado da Santa Casa e passar a ser subordinado à administração pública (Brasil, 15 fev. 1890).

${ }^{5}$ Em 1911 o Pavilhão de Observação foi ampliado, criando-se, em seu âmbito, o Instituto de Psicologia Experimental e o Instituto de Neuropatologia, que comportava então os pavilhões de Admissão, Neuropatologia e Doenças Nervosas. Vinte e dois anos depois, o presidente Getúlio Vargas transformouo no Instituto de Psiquiatria da Universidade do Brasil, atual Universidade Federal do Rio de Janeiro (Brasil, 3 ago. 1938). 
${ }^{6}$ A partir de 1909, os relatórios ministeriais não mencionam mais a Casa de Saúde S. Sebastião como parte da Assistência.

${ }^{7}$ Em 1932 o Laboratório se transformou no Instituto de Psicologia, uma extensão do curso de Psicologia e Psiquiatria da Universidade do Brasil.

${ }^{8}$ O SNDM foi instituído pelo decreto-lei 3.171, 1941, como um dos 23 órgãos do recém-estruturado Departamento Nacional de Saúde, do Ministério da Educação e Saúde (Brasil, 2 abr. 1941). O Departamento compreendia as Divisões de Saúde Pública, de Assistência Hospitalar, de Assistência a Psicopatas e de Amparo à Maternidade e à Infância. Transformou-se na Divisão Nacional de Saúde Mental (Dinsan) na década de 1960 (Melloni, 2009).

${ }^{9}$ Desde o início de sua gestão, Adauto Botel ho queria transferir o Hospício Nacional de Alienados da Praia Vermelha para o recém-criado Centro Psiquiátrico Nacional.

${ }^{10} \mathrm{Na}$ década de 1940, o Centro Psiquiátrico Nacional passou a compreender as seguintes instituições: Hospital Gustavo Riedel (herdeiro da antiga colônia); Hospital de Neuro-psiquiatria Infantil (1942), que absorveu as crianças internas no Hospício Nacional e na Colônia Juliano Moreira; Hospital Pedro II (1943), que recebeu os pacientes do antigo Hospício Nacional; Bloco Médico Cirúrgico (1948), hospital de oito pavimentos destinado à internação clínica, cirúrgica e obstétrica dos pacientes psiquiátricos de todo o estado do Rio de Janeiro (Oliveira, 2004).

${ }^{11} \mathrm{O}$ antigo prédio do Instituto de Psiquiatria da Praia Vermelha foi entregue à Universidade do Brasil juntamente com o do Instituto de Psicopatologia. O Instituto de Neuro-sífilis, hoje Instituto Pinel, embora tenha continuado na Praia Vermelha, manteve-se subordinado ao Centro Psiquiátrico Nacional.

${ }^{12}$ Devido ao aumento do número de homens considerados de alta periculosidade - enviados pela delegacia de polícia ao Hospício Nacional e chamados nos relatórios de 'delinquentes' -, foi criada na Seção Pinel, em 1917, a subseção de nome Seção Lombroso, destinada a abrigar esses doentes, ficando a cargo dela Heitor Carrilho (Brasil, MJNI, 1922). Ressalte-se que, mesmo antes da construção dessa seção, são muitos os relatórios em que o diretor da Assistência insiste na necessidade da criação de um manicômio judicial. Sobre o Manicômio Judiciário, ver Carrara, 1998.

${ }^{13}$ A partir de 1954, com o falecimento de Heitor Carrilho, o Manicômio Judiciário do Rio de Janeiro passou a denominar-se Manicômio Judiciário Heitor Carrilho (Amarante, 2004).

14 O engenho foi desapropriado em 1912 por recomendação do doutor João Augusto Rodrigues Caldas, que buscava novo espaço para abrigar as duas antigas colônias da Ilha do Governador, cujos prédios eram considerados inadequados. Em 1918 o governo brasileiro liberou as terras do antigo engenho, e no ano seguinte começou a construção da então Colônia de Psicopatas-homens, renomeada Colônia Juliano Moreira em 1935 (Venancio, 2008, p.6).

15 Órgão da administração central, criado em 1822 com o nome de Secretaria de Estado dos Negócios da Justiça (Brasil, 3 set. 1822). Na República teve seu nome alterado para Ministério da Justiça e Negócios Interiores (Brasil, 30 out. 1891). Tinha como atribuições, entre outras, defender a ordem jurídica, os direitos políticos, as garantias constitucionais e prover a assistência jurídica, judicial e extrajudicial, integral e gratuita aos necessitados, assim considerados em lei. Passou a denominar-se Ministério da Justiça em 1967 (Brasil, 25 fev. 1967).

${ }^{16}$ Sobre a importância de Capanema no Mesp entre 1934 e 1945, ver Fonseca, 2007.

${ }^{17}$ Entretanto, pode-se afirmar que os acervos pesquisados abrigam documentos clínicos produzidos de 1841 (Anexo para Alienados da Santa Casa) até a década de 1960.

18 Para detalhamento da metodologia de armazenamento desses dados, ver Facchinetti, Ribeiro, 2008.

${ }^{19}$ Como resultado, temos hoje uma estrutura de informações, na Base de Documentos Clínicos, com 38 campos, sendo oito deles ocultos (nome, médico, diretor, médico de alta/fal ecimento, outras identidades, número de registro e observação do pesquisador), para controle da equipe de pesquisa. A base conta hoje com dados sobre cerca de 3.500 documentos clínicos.

20 Os prontuários são assinados pelos diretores do Hospital, os médicos Afrânio Peixoto, Antonio Dias de Barros, Domingos Araújo, Juliano M oreira e Sá Ferreira. Também os médicos responsáveis pelas seções e pelo diagnóstico da causa mortis assinavam os prontuários: Afrânio Peixoto; Álvaro Ramos; Antonio Austregésilo; Antonio Dias de Barros; Antonio Galotti; Ayrosa; Braule Pinto; Domingos Araújo; Fernandes Figueira; Gustavo Riedel; Henrique Sampaio; Humberto Gotuzzo; Juliano Moreira; Lúcio de Oliveira; Márcio Nery; Miguel Pereira; Rocha Vaz; Ulisses Vianna Filho; Faustino Esposel, entre outros. 
${ }^{21}$ A primeira mudança na configuração dos prontuários se deu em 1906 e a segunda, de menor escala, em 1910 - o que, por si, já fornece el ementos para análise. É preciso lembrar que em 1905 Juliano Moreira e Afrânio Peixoto iniciaram um processo classificação psiquiátrica apoiada em Kraepelin, bem como deram o pontapé inicial na divulgação científica através da fundação da Arquivos... . A proposta da nova classificação foi desdobrada, a partir de 1908, em uma comissão que visava uniformizar as classificações nosográficas brasileiras, medida que só foi levada a termo pela Sociedade Brasileira de Neurologia e Psiquiatria em 1919.

${ }^{22}$ Sobre Juliano Moreira, ver nota 2 do artigo "Arquivos Brasileiros de Psiquiatria, Neurologia e Ciências Afins: uma fonte com muita história", neste número de História, Ciências, Saúde - Manguinhos.

23 "O cronógrafo projetado por Hipp uniu de forma significativa a precisão da passagem do tempo com a determinação objetiva do tempo. A precisão era assegurada através do impulso dos pesos do relógio. O mecanismo do mostrador era colocado em movimento ou parado através de contatos el etromagnéticos. $\mathrm{Na}$ relação com os correspondentes fornecedores de contatos foi possível ler diretamente tempos de reação. ... As estimativas de tempo representaram um papel importante especialmente nas observações das reações a estímulos óticos e acústicos, tal como elas eram efetuadas nos inícios da psicologia experimental" (Uerj, s.d.).

${ }^{24}$ Ressalte-se que os Relatórios são datados, em geral, de abril, maio, junho ou julho, e relatam acontecimentos do ano anterior e dos primeiros meses do ano em que foram escritos.

${ }^{25}$ Foram selecionados aqueles produzidos entre os anos de 1900 e 1930, porém não foram encontrados os relatórios referentes a 1920, 1926, 1929 e 1930; e o relatório concernente a 1925 não faz referência à Assistência a Alienados. Os relatórios ministeriais estão disponíveis no site do Center for Research Libraries (disponível em: http://www.crl.edu.; acesso em 11 jul. 2010).

${ }^{26}$ Foram nomeados, pelo ministro da Justiça e Negócios Interiores, o farmacêutico Francisco Manuel da Silva Araújo; e os médicos Antonio Maria Teixeira; Carlos Fernandes Eiras; Egydio de Salles Guerra (Brasil, MJNI, 1903, anexo B).

${ }^{27}$ Até 1903 o Hospício Nacional era dividido em quatro grandes seções: para pensionistas, a Seção Morel (para mulheres) e a Calmeil (para homens); para os doentes mantidos pelo Distrito Federal, a Esquirol (para mulheres) e a Pinel (para homens). Não havia seção especial para crianças.

${ }^{28}$ Segundo Afrânio Peixoto (1905), esse gabinete servia "à sinalética para a identificação e registro étnico" e o serviço de fotografia a ele relacionado, para conservação da foto do doente, que deveria se juntar a sua observação.

${ }^{29}$ Em 1905, o Laboratório de Anatomia Patológica estava ainda sendo construído para uso “histológico, químico e bacteriológico". Mas Peixoto observa que o Hospício já adquirira para ele alguns aparelhos, como o "de Zeiss, Lautentschläger, Tromme, Leutz", entre outros.

30 Em 1904 Juliano Moreira tirou licença para tratamento de tuberculose, deixando Afrânio Peixoto como diretor. Amigo pessoal do ministro Seabra, Afrânio apresentara Juliano Moreira e propusera seu nome para a direção do Hospício Nacional e da Assistência. É possível que sua permanência, naquele ano, tenha facilitado a obtenção de apoio financeiro para as reformas nas instituições da Assistência (Brasil, MJNI, 1904).

${ }^{31}$ As seções do Hospício Nacional, identificadas na pesquisa, são: Primeira (Pinel), Segunda (Esquirol), Alaor Prata, Bourneville, Calmeil, Cirurgia, Esquirol, Francisco de Castro, Griesinger, Guinle, Guislan, Lombroso, Morel, Nina Rodrigues, Pinel e Sigaud. Em 1915 cita-se pela primeira vez o Laboratório de Química e Biologia e no ano seguinte, o Serviço de Fisioterapia (Brasil, MJNI, 1915, 1916).

32 Reiterados pedidos são feitos, nos relatórios ministeriais (Brasil, MJNI, 1910, 1911, 1912, 1913), para a criação de colônias para alcoólatras e para epilépticos.

${ }^{33} \mathrm{Em} 1907$ as seções Esquirol e Pinel deveriam abrigar 250 doentes, contudo a primeira abrigava 382 pacientes e a segunda, 390; eram as seções mais lotadas do Hospício. Em 1908 a seção Pinel abrigava 414 doentes e a Esquirol 374, e a superlotação também vinha atingindo outras seções, como a Morel (para pensionistas mulheres) e Calmeil. No ano de 1909, os internados na seção Esquirol atingiram 385 pacientes, ou seja, 135 pessoas a mais que sua capacidade (Brasil, MJNI, 1907,1908, 1909).

${ }^{34}$ Com o aumento do número de alienados e, por consequência, o de tuberculosos, construiu-se, nos fundos do terreno, um pequeno pavilhão-varanda para tratar esses pacientes (Brasil, MJNI, 1908).

${ }^{35}$ De acordo com Afrânio Peixoto (1905), o serviço de eletroterapia era novo, importado da Alemanha. Constava de banho de luz e banho hidroelétrico para correntes galvânicas (aplicação de correntes 
elétricas contínuas), farádicas (corrente induzida, de duração momentânea e com potencial bastante mais al to) e al ternativas sinuosoidais (de correntes crescentes ou decrescentes), com banhei ra que permitia várias aplicações; aparel ho de adaptação para galvanização, el etrólise, cataforese, faradização, endocospia e cáustica; instalação produtora e utilizadora de raios Roentgen, combinada com correntes alternativas de alta frequência (d'arsonvalização); ozonizador Oudin, para produção de ozona; aparelho FinsenReyn, para aplicações fototerápicas; máquina estática de Wimshurt autoexcitadora, para aplicações franklinianas; instalação para eletrodiagnóstico

${ }^{36}$ Tratamento individualizado, tendo por base de repouso no leito. Era contraindicado aos alienados tranquilos, inofensivos e de boa nutrição (Cabred, 1909). Para Juliano Moreira (1908, p.172), a clinoterapia era um modo bastante eficiente de reprimir a violência, em lugar da camisa de força.

${ }^{37}$ A cinesioterapia, também conhecida como ginástica médica, foi utilizada no Hospício por meio de aparel hos para ginástica médica, massagem vibratória e reeducação de movimentos: mesa de massagem Zabludowsky, resistência de pedal para ginástica de membros inferiores, aparel ho rotador do tronco com velocípede fixo, aparelho para remar, ergostato, escada Nebenstreppe para exercício, barra Lautbarren para apoio e marcha, carro para reeducar a marcha etc. (Peixoto, 1905).

38 Tratamento por meio de banhos. No hospício, o serviço abrigava duas instaçãoes, uma "para cada sexo, além do serviço de banhos permanentes e privativos, para cada seção". O serviço de duchas compunha-se de "duchador, duchas escocesas, em círculo, em rótulo e de assento". Além disso, trinta banheiras disseminadas pelo Hospício permitiam "o uso de banhos prolongados". Havia, ainda, "dois sudorários e um pulverizador de essências (Peixoto, 1905).

${ }^{39}$ Não nos foi possível identificar o fotógrafo das imagens aqui reproduzidas, que assinava as imagens com as iniciais NI, sobrepostas.

${ }^{40}$ Por meio do relatório de 1905, ficamos sabendo que tais modificações seriam feitas também nas colônias existentes no Rio de Janeiro. Entretanto, ao contrário do que aconteceu com a instituição inserida na malha urbana, as reiteradas solicitações de recursos para ampliação e reforma das colônias não foram autorizadas com a mesma velocidade e consistência. Assim, o Hospício Nacional permaneceu, na primeira década do século XX, como modelo exclusivo para o tratamento de alienados, registrado nas imagens então produzidas.

\section{REFERÊNCIAS}

ABNP.

Archivos Brasileiros de Neuriatria e Psychiatria. Rio de Janeiro: Sociedade Brasileira de Neurologia, Psiquiatria e Medicina Legal. 1919-1921; 1924; 1927-1940.

ABPCA.

Archivos Brasileiros de Psychiatria e Sciencias Affins. Rio de Janeiro. 1905-1907.

ABPNML.

Archivos Brasileiros de Psychiatria, Neurologia e Medicina Legal. Rio de Janeiro: Sociedade Brasileira de Neurologia, Psiquiatria e Medicina Legal. 1908-1914; 1916.

ALMEIDA, Marta de. Entre balões, carrosséis e ciências: a exposição internacional de higiene na capital federal. In: Encontro Regional de História Anpuh-RJ: Usos do passado, 12. 2006, Niterói. Anais... Rio de Janeiro: Associação Nacional de Pesquisadores em História-RJ. p.1-10. 2006.

AMARANTE, Paulo (Ed.)

Guia de fontes e catál ogo de acervos e instituições para pesquisas em saúde mental e assistência psiquiátrica no estado do Rio de Janeiro. Rio de Janeiro: Laps/Ensp/Fundação Oswaldo Cruz. Disponível em: http:// www4.ensp.fiocruz.br/eventos_novo/dados/ arq423.pdf. Acesso em: 23 jun. 2010. 2004.

AMARANTE, Paulo.

Psiquiatria social e colônias de alienados no Brasil (1830-1920). Dissertação (M estrado) - Instituto de Medicina Social, Universidade do Estado do Rio de Janeiro, Rio de Janeiro. 1982.

BRASIL.

Decreto-lei n.200, de 25 de fevereiro de 1967. Dispõe sobre a organização da Administração Federal, estabelece diretrizes para a Reforma Administrativa e dá outras providências. 25 fev. 1967.

BRASIL.

Decreto n.20.889, de 30 de dezembro de 1931. Desliga do Departamento Nacional de Saúde Pública a Assistência a Psicopatas e o Manicômio Judiciário. 30 dez. 1931

BRASIL.

Decreto n.5.148-A, de 10 de janeiro de 1927. 
Reorganiza a Assistência a Psicopatas no Districto Federal. 10 jan. 1927.

BRASIL.

Decreto n.17.805, de 23 de maio de 1927. Aprova o regulamento para execução dos serviços da Assistência a Psicopatas no Distrito Federal. 23 maio 1927.

BRASIL.

Decreto n.14.831, de 25 de maio de 1921. Aprova o regulamento do Manicômio Judiciário. 25 maio 1921.

BRASIL.

Decreto n.1.132, de 22 de dezembro de 1903. Reorganiza a Assistência a Alienados. 22 dez. 1903.

BRASIL.

Decreto n.206, de 15 de fevereiro de 1890. Aprova as instruções a que se refere o decreto número 142-A ... e cria a Assistência Médica e Legal de Alienados. 15 fev. 1890.

BRASIL.

Decreto n.0-035, de 3 setembro de 1822. Cria a Secretaria de Estado dos Negócios da Justiça. 3 set. 1822.

BRASIL.

Decreto-lei n.3.171, de 2 de abril de 1941.Reorganiza o Departamento Nacional de Saúde, do Ministério da Educação e Saúde, e dá outras providências. 2 abr. 1941.

BRASIL.

Decreto-lei n.591, de 3 de agosto de 1938. Transfere para a Universidade do Brasil o Instituto de Psicopatologia do Serviço de Assistência a Psicopatas do Distrito Federal e dá outras providências. 3 ago. 1938.

BRASIL.

Lei n.23, de 30 de outubro de 1891. Reorganiza os serviços da administração federal.

30 out. 1891.

BRASIL.

Ministério da Justiça e Negócios Interiores (MJNI). [Relatórios ministeriais]. Disponível em: http://www.crl.edu.. Acesso em: 11 jul. 2010. 1892-1928.

CABRED, Domingo Felipe.

La clinoterapia en las enfermedades mentales. Archivos Brasileiros de Psychiatria, Neurologia e Medicina Legal, Rio de Janeiro, n.3-4, p.396-413. 1909.

\section{CARRARA, Sérgio.}

Crime e loucura: o aparecimento do manicômio judiciário na passagem do século. Rio de Janeiro: EdUERJ. 1998.

CASSÍLIA, Janis; VENANCIO, Ana.

História da política assistencial à doença mental (1941-1956): o caso da Colônia Juliano Moreira no Rio de Janeiro. In: Simpósio Nacional de História - Anpuh, 24. 2007, São Leopoldo. Anais... São Leopoldo: Unisinos. Disponível em: http://snh2007.anpuh.org/ resources/content/anais/Ana\%20Teresa\%20 Venancio.pdf Acesso em: 24 ago. 2010. 2007.

COFFIN, Jean.

La transmission de la folie, 1850-1914. Paris: Hartmattan. 2003.

CUNHA, Maria Clementina Pereira.

O Espel ho do mundo: Juquery - a história de um asilo. Rio de Janeiro: Paz e Terra. 1986.

ENGEL, Magali Gouveia.

Os delírios da razão: médicos, loucos e hospícios (Rio de Janeiro, 1830-1930). Rio de Janeiro:

Ed. Fiocruz. 2001.

ENGSTROM, Eric.

On the question of degeneretion by Kraepelin. History of Psychiatry, London, v.18, p.389-397. 2007.

FACCHINETTI, Cristiana.

Da loucura à alienação mental: o Hospício Nacional de Alienados entre 1910 e 1939.

Relatório de Pesquisa de pós-doutoramento. apoio CNPq-Fiocruz. 2006.

FACCHINETTI, Cristiana.

Diagnósticos de uma nação: discursos e práticas revelados pelo acervo do Hospício Nacional de Alienados. Relatório de Pesquisa de recém-doutoramento. Rio de Janeiro, Casa de Oswaldo Cruz/Fiocruz, apoio CNPq-Fiocruz. 2005.

FACCHINETTI, Cristiana.

Saúde mental no Brasil: confluências entre psiquiatria, higiene mental e psicanálise (19001930) Relatório de Pesquisa de recémdoutoramento. Rio de Janeiro, Casa de Oswaldo Cruz/Fiocruz, apoio CNPq-Fiocruz. 2004.

FACCHINETTI, Cristiana; EDLER, Flávio C.; VENANCIO, Ana Tereza.

A prática psiquiátrica e o campo biomédico no Brasil (1900-1960). Relatório de pesquisa. Rio de Janeiro, Casa de Oswaldo Cruz/Fiocruz, apoio Faperj. 2007.

FACCHINETTI, Cristiana; RIBEIRO, Andrea. Fontes históricas em rede: o caso da história da psiquiatria no Brasil. Textos de la CiberSociedad, n.16. Disponível em: http://www.ciber sociedad.net/textos/articulo.php?art=210. Acesso em: 15 ago. 2010. 2008.

FACCHINETTI, Cristiana; RIBEIRO, Andréa; MUÑOZ, Pedro F. de. As insanas do Hospício Nacional de Alienados 
(1900-1939). História, Ciências, Saúde - Manguinhos, Rio de Janeiro, v.15, supl., p.231-242. 2008.

FONSECA, Cristina M. de Oliveira. Saúde no governo Vargas (1930-1945): dualidade institucional de um bem público. Rio de Janeiro: Ed. Fiocruz. 2007.

FOUCAULT, Michael.

O poder psiquiátrico. São Paulo: Martins Fontes. 2006.

FOUCAULT, Michael.

História da loucura. São Paulo: Perspectiva. 1978.

FIOCRUZ.

Fundação Oswaldo Cruz. Casa de Oswaldo Cruz. Base de dados Psi-coc. Rio de Janeiro. Coord., Cristiana Facchinetti. 2008.

JABERT, Alexander.

De médicos e médiuns: medicina, espiritismo e loucura no Brasil da primeira metade do século XX. Tese (Doutorado) - Programa de Pós-graduação em História das Ciências e da Saúde, Casa de Oswaldo Cruz, Fundação Oswaldo Cruz, Rio de Janeiro. 2008.

JABLENSKY, Assen.

Living in a Kraepelinian world: Kraepelin's impact on modern psychiatry. History of Psychiatry, London, v.18, p.381-388. 2007.

JACÓ-VILELA, Ana Maria; ESPÍRITO SANTO, Adriana Amaral do; PEREIRA, Vivian F. Studart.

Medicina legal nas teses da Faculdade de Medicina do Rio de Janeiro (1830-1930): o encontro entre medicina e direito, uma das condições de emergência da psicologia jurídica. Interações: Estudos e Pesquisas em Psicologia, São Paulo, v.10, n.19, p.9-34. 2005.

KOSSOY, Boris.

Fotografia \& história. 2. ed. rev. São Paulo: Ateliê Editorial. 2001.

LAUDO DE EXAME...

Laudo do exame de sanidade mental.

Manicômio Judiciário. (Hospital de Custódia e Tratamento Psiquiátrico Heitor Carrilho). 1934.

LAUDO DE EXAME...

Laudo do exame de sanidade mental.

Manicômio Judiciário. (Hospital de Custódia e

Tratamento Psiquiátrico Heitor Carrilho).

1932a.

LAUDO DE EXAME...

Laudo do exame de sanidade mental.

Manicômio Judiciário. (Hospital de Custódia e Tratamento Psiquiátrico Heitor Carrilho). 1932b.
LAUDO DE EXAME...

Laudo do exame de sanidade mental.

Manicômio Judiciário. (Hospital de Custódia e Tratamento Psiquiátrico Heitor Carrilho).1929.

\section{LAUDO DE EXAME...}

Laudo do exame de sanidade mental.

Manicômio Judiciário. (Hospital de Custódia e Tratamento Psiquiátrico Heitor Carrilho).1928.

LAUDO DE EXAME...

Laudo do exame de sanidade mental.

Manicômio Judiciário. (Hospital de Custódia e Tratamento Psiquiátrico Heitor Carrilho).1927.

\section{LAUDO DE EXAME...}

Laudo do exame de sanidade mental.

Manicômio Judiciário. (Hospital de Custódia e Tratamento Psiquiátrico Heitor Carrilho). 1924.

\section{LIVRO DE OBSERVAÇÃO.}

Manicômio Judiciário. (Hospital de Custódia e Tratamento Psiquiátrico Heitor Carrilho). 1922.

MACHADO, Roberto et al.

Danação da norma: medicina social e constituição da psiquiatria no Brasil. Porto: Graal. 1978.

\section{MEDEIROS, Maurício de.}

A questão dos métodos em psicologia. Archivos Brasileiros de Psychiatria, Neurologia e M edicina Legal, Rio de Janeiro, n.1-2, p.23-51. 1908.

MELLONI, Maria Teresa.

O movimento psicanalítico no Brasil (1937-

1959): efeitos de um processo de institucionalização. Rio de Janeiro: Dissertação (Mestrado) - Programa de Pós-graduação em História das Ciências e da Saúde, Casa de Oswaldo Cruz, Fundação Oswaldo Cruz, Rio de Janeiro. 2009.

MENEZES, Ulpiano T. Bezerra de. Fontes visuais, cultura visual, história visual: balanço provisório, propostas cautelares. Revista Brasileira de História, São Paulo, v.23, n.45, p.11-36. 2003.

MOREIRA, Juliano. Querelantes e pseudo-querelantes. Archivos Brasileiros de Psychiatria, Neurologia e M edicina Legal, Rio de Janeiro, n.3-4, p.426-433. 1908.

MUÑOZ, Pedro Felipe Neves de. Degeneração atípica: uma incursão ao arquivo de Elza. Dissertação (Mestrado) - Programa de Pós-graduação em História das Ciências e da Saúde, Casa de Oswaldo Cruz, Fundação Oswaldo Cruz, Rio de Janeiro. 2010.

\section{O IX MANDAMENTO...}

O IX Mandamento - ainda o caso da senhora alemã mantida em cárcere privado - uma carta trazida a esta redação. 0 Jornal, Rio de Janeiro, p.6. 14 jul. 1925. 
OLIVEIRA, Edmar.

Engenho de Dentro do lado de fora: território comum com um engenho novo. (Monografia de Gestão de Saúde) - Fundação João Goulart, Rio de Janeiro. 2004.

PEIXOTO, Afrânio.

Hospício Nacional de Alienados. Archivos Brasileiros de Psychiatria e Sciencias Affins, Rio de Janeiro, n.1, p.106-120. 1905.

PORTOCARRERO, Vera M.

Juliano Moreira e a descontinuidade histórica da psiquiatria. Rio de Janeiro: Ed. Fiocruz. (Coleção Loucura e Civilização). 2002.

PRONTUÁRIO.

Hospital Nacional de Alienados; Seção Lombroso, Distrito Federal. (Hospital de Custódia e Tratamento Psiquiátrico Heitor Carrilho). 1923.

PRONTUÁRIO.

Hospício Nacional, Distrito Federal. (Instituto Municipal de Assistência à Saúde Nise da Silveira). 1909.

PRONTUÁRIO.

Hospício Nacional, Distrito Federal. (Instituto Municipal de Assistência à Saúde Nise da Silveira). 1902.

PRONTUÁRIO Hospital Nacional de Alienados; Seção Lombroso, Distrito Federal. (Hospital de Custódia e Tratamento Psiquiátrico Heitor Carrilho). 1919.

\section{RELATÓRIO TÉCNICO...}

Relatório técnico da Comissão de Inquérito sobre as condições da Assistência a Alienados no Hospício Nacional e colônias da Il ha do Governador, 1902. In: Brasil. Ministério da Justiça e Negócios Interiores. Relatório apresentado ao presidente da República dos Estados Unidos do Brasil pelo dr. J.J. Seabra. Anexo B. Rio de Janeiro: Imprensa Nacional. Disponível em: http://brazil.crl.edu/bsd/bsd/ u1887/000443.html. Acesso em: 11 jul. 2010. 1903.

ROCHA, Francisco Franco da. Hospício de São Paulo: fragmentos de Psychiatria. Revista Latinoamericana de Psicopatologia Fundamental, São Paulo, v.6, n.3, p.164-179. 1.ed., 1895. 2003.

ROSENBERG, Charles; GOLDEN, J. (Ed.). Framing disease: studies in cultural history. New Brunswick: Rutgers University Press. 1992.

ROXO, Henrique de Brito Belford.

Manual de psiquiatria. 2.ed. Rio de Janeiro: Guanabara. 1925.

ROXO, Henrique de Brito Belford.

Causas de reinternação de alienados no
Hospício Nacional. Archivos Brasileiros de Psychiatria, Neurologia e Medicina Legal, Rio de Janeiro, n.3-4, p.403-415. 1910.

\section{SANTOS, Nadia.}

Narrativas da loucura e histórias de sensibilidades. Porto Alegre: EdUFRGS. 2008.

SONTAG, Susan.

Uma foto não é uma opinião - ou é? In: Sontag, Susan. Questão de ênfase: ensaios. São Paulo: Companhia das Letras. p.306-322. 2005.

SONTAG, Susan.

Sobre fotografia. São Paulo: Companhia das Letras. 2004.

UERJ.

Universidade do Estado do Rio de Janeiro.

Clio-Psyché - Programa de Estudos e Pesquisas em História da Psicologia. Cronoscópio de Hipp. Disponível em: http://www.cliopsyche. uerj.br/arquivo/instrumentos/cronoscopio. html. Acesso em: 25 out. 2010. s.d.

VENANCIO, Ana Teresa A.

A Colônia Juliano Moreira na década de 1940: política assistencial, exclusão e vida social. In: Congresso Internacional de Psicopatologia Fundamental, 3.; Congresso Brasileiro de Psicopatologia Fundamental, 9 - Pathos: violência e poder, 2008, Niterói. Anais... Niterói: Associação Universitária de Pesquisa em Psicopatologia Fundamental,. Disponível em: http://www.fundamental psychopathology.org/ 8_cong_anais/MR_34c.pdf. Acesso em: 4 ago. 2010. 2008.

VENANCIO, Ana Teresa A.

As faces de Juliano Moreira: Iuzes e sombras sobre seu acervo pessoal e suas publicações. Estudos Históricos: Antropologia e Arquivos, São Paulo, v.2, n.36, p.59-73. 2005.

WADI, Yonissa M.

Palácio para guardar doidos: uma história das lutas pela construção do Hospital de Alienados e da psiquiatria no Rio Grande do Sul. Porto Alegre: EdUFRGS. 2002.

WADI, Yonissa M.

Quem somos nós, loucos!?: um ensaio sobre limites e possibilidades de reconstituição histórica de trajetórias de vida de pessoas internas como loucas. Anos 90, Porto Alegre, v.13, n.23-24, p.87-319. 2006.

WEBER, Matthias M.; BURGMAIR, Wolfgang; ENGSTROM, Eric J.

Emil Kraepelin (1856-1926): zwischen klinischen Krankheitsbildern und 'psychischer Volkshygiene'. Deutsches Ärzteblatt, Köln, v.103, p.A2685-A2690. 2006. 